\title{
HOAXVILLE: READING PEREC READING JOYCE
}

This essay explores Perec's fascination with Joyce and the influential role played by Ulysses in the development of his avant-gardist writing practices. Whilst acknowledging Perec's cautious receptiveness to a number of contemporary cultural currents and the formative significance of his involvement in the OuLiPo, the piece highlights the extent of his lifelong engagement with Joyce, and argues for a connection between the different, but equally extreme forms of intertextuality cultivated by both writers. Focusing on the extraordinarily artful ways in which quotations from Ulysses are deployed in Life A User's Manual (1978), it identifies the many and complex ways in which Perec's rule-governed intertextual system draws on and departs from Joyce's precedent.

\section{Perec, avant-gardiste?}

At the time of his death in 1982, Georges Perec had been a recognized figure of France's literary avant-garde for seventeen years. In 1965, his first novel, Things, had been awarded the Prix Renaudot, ${ }^{1}$ and since then Perec had been, if not exactly in the limelight, then at least a man to watch. In 1978 Life A User's Manual, the work now widely considered to be his masterpiece, was awarded the Prix Médicis, confirming his position in the national consciousness as an author of the very first rank. ${ }^{2}$

Although Perec was 'never particularly interested in literary society, even when literary society became interested in him ', ${ }^{3}$ his friendships, literary enthusiasms, and Parisian context brought him into contact with the members of a number of movements and avant-gardes. His enthusiasms were not modish, however. Especially early on in his writing life, he was forthrightly dismissive of certain of his eminent contemporaries, "view[ing] "committed literature" as old hat, and refus[ing] to take seriously the work of the "new novelist" Alain Robbe-Grillet'. ${ }^{4}$ On the other hand, however, he was partial to the writings of Michel Butor, whom he later credited as the source of his conception of literature as a jigsaw puzzle. ${ }^{5}$

In 'the age of the media guru', Perec expressed contempt for what he saw as the empty posturing of Tel Quel, referring to 'Philippe Sollers and his friends', for instance, as 'filthy sods'. ${ }^{6}$ For all its vehemence the attack was typical rather than unique, and reflects Perec's increasing impatience, in the mid-60s, with the contamination of intellectual culture by academic fashion. In the same article as he insulted the telquelliens, Perec lampooned what Bellos calls 'the haute couture of the mind':

Now on the cat-walk, the latest creation from EPHE... This daring cutaway design comes from the CNRS... The Collège de France has chosen a structuralist

\footnotetext{
${ }^{1}$ The Prix Renaudot was set up in 1926 as an unofficial complement to the very prestigious Prix Goncourt, with the winners of both being declared on the same day in November. The jurors of the Renaudot always choose two possible winners: in the event of the Goncourt being awarded to one, the Renaudot goes to the other. In 1965, recent recipients of the Renaudot included Michel Butor (1957) and J.M.G. Le Clézio (1963).

${ }^{2}$ Founded in 1958, the Prix Médicis is awarded to an author 'whose fame does not yet match his talent' http://prixmedicis.wordpress.com/lhistoire/ [site accessed 28 November 2016].

${ }^{3}$ David Bellos, Georges Perec, A Life in Words [1993], revd edn (London: The Harvill Press, 1999), 146.

${ }^{4}$ Bellos, 199. It was in large part thanks to Robbe-Grillet's support that Perec was awarded the Prix Médicis for Life A User's Manual two decades later.

5 Perec first read Michel Butor's L'Emploi du Temps [1956] in 1960 or 1961, subsequently studying his essay on

'Le roman comme recherche' ('The Novel as Experiment'). - Bellos, 247.

${ }^{6}$ Perec, 'L'Esprit des Gens' in Arts-Loisirs, 25 October 1966, quoted and translated in Bellos, 355.
} 
wraparound... Mini-concepts are back in vogue... but the Sorbonne favours a lower psychoanalytical hem line... A brilliant young designer from ENS is sure to steal the show with a delightfully eclectic little cogito. $^{7}$

Likewise, he remained largely uninvolved in the May '68 uprisings with which so many selfconsciously avant-gardist figures sought to associate themselves, electing to stay away from the capital 'during the days of rioting and passion' and to 'keep his views on the current political scene to himself' ${ }^{8}$

Yet for all his mordant parodic energies and wariness of political involvement, Perec was in fact highly receptive to particular strands of contemporary cultural theorizing. In 1958, he became acquainted with Henri Lefèbvre, the first volume of whose Critique de la Vie Quotidienne had just been published. The book's impact on Things, in which Perec examines the everyday from a sociological perspective, is plain to see. ${ }^{9}$ With 'A Story of the Sixties' as its subtitle, and written under the dominant and acknowledged influence of Flaubert's Sentimental Education, the novel depicts a young middle-class couple's ambivalent, oscillating relationship to the materialistic universe of consumable 'things' in which they are embedded. According to Bellos, 'Things is not just a fictional recreation of Lefèbvre's Critique, but a theoretical philosopher might easily believe that it was. ${ }^{10}$ In 1963 Perec (who had previously abandoned his university degree in 1957 at the age of 21) enrolled as a student at the Sorbonne in order to attend the Marxist philosopher Lucien Goldmann's lectures on the sociology of literature. ${ }^{11} \mathrm{He}$ obtained permission from Roland Barthes (to whom he had been briefly introduced at a writers' retreat at Royaumont in 1955) to audit his lectures, following his course on semiology in 1963 and on rhetoric in 1964. ${ }^{12}$ Much later, in 1980, Perec would refer to Barthes' seminar on advertising language as his 'most important' model for Things. ${ }^{13}$

Bellos mentions the Situationists as another contemporary theoretical development whose influence on Perec can be called 'certain'. With Guy Debord at the helm, the Situationists, whose manifesto appeared in 1960, thought of themselves as 'revolutionary gamesters' intent

\footnotetext{
${ }^{7}$ Ibid., 354. The acronyms refer to the following Parisian academic institutions: the École Pratique des Hautes Études (EPHE), the Centre National de la Recherche Scientifique (CNRS), the École Nationale Supérieure (ENS). ${ }^{8}$ Bellos, 401.

${ }^{9}$ In 1978, Perec himself named the 'sociological' approach as one of four 'modes of interrogation' his works have assumed in describing the world. Things is the first named example of this approach. - Georges Perec, 'Notes sur ce que je cherche', Le Figaro, 8 December 1978, reproduced in Georges Perec, Penser/Classer (Paris: Hachette, 1985), 10.

${ }^{10}$ Bellos, 192.

${ }^{11}$ Bellos, 134-5 and 287.

12 Bellos, 146, 287, 289.

${ }^{13}$ Georges Perec, 'Emprunts à Flaubert', in L'Arc, 76, 1980, 49-50, 49. As early as 1965, Perec had been willing to state that 'the book was in the beginning two different plans: first an exercise on Barthes's Mythologies, that's to say, on advertising language as it is reflected within us; then a barely heightened description of a particular social set, which happens to be my own.' - Georges Perec, with Marcel Bénabou and Bruno Marcenac, 'Georges Perec Owns Up: An Interview', trans. David Bellos, in Review of Contemporary Fiction, 'Georges Perec Issue', Vol. 29, Issue 1, Spring 2009, 25-30, 27. When Perec sent him a draft of Things in January 1964, Barthes, who almost certainly recognized his influence, responded with fulsome approval: 'I find your book extremely good. I believe I can sense all the novelty you expect from it [...] A novel or a story about poverty inextricably bound up with the image of wealth is very beautiful, [and] very rare nowadays. I don't know what you want to revise or add to it, but in any case finish it quickly - and publish!' - Bellos, 298-9. On Perec's engagement with Barthes in Things and A Man Asleep, see Andrew Leak. 'Phago-Citations: Barthes, Perec, and the Transformation of Literature', in 'Georges Perec Issue', Review of Contemporary Fiction (29:1) Spring 2009, 124-147.
} 
on unleashing 'primitive ludic tendencies'. ${ }^{14}$ Their investment in plagiarism as 'the only true originality' and in 'modified unacknowledged quotation' as a virtue rang in tune with Perec's own fascination with second-hand language - with what Julia Kristeva, in 1966, would term 'intertextuality'. ${ }^{15}$

For all his acquaintance with a range of influential theorists and artists, it was only after joining the OuLipo in 1967 that Perec was to find himself at home within an active literary avant-garde. The OuLiPo, or Ouvroir de littérature potentielle, considered itself to be 'a group', rather than 'a movement' - a humble 'workshop' dedicated to the exploration of literature's mathematical and ludic potentialities. ${ }^{16}$

Perec's life and works can thus fruitfully be situated at the intersection of a number of cultural currents. Yet the account given so far leaves out a crucial dimension of Perec's idiosyncrasy as a writer - namely, the internationalism of his literary interests, and, specifically, his captivation with Joyce. The remainder of this essay adds to this picture by shining a light on the extent and ingenuity of Perec's response to the extreme intertextuality of Joyce's works.

\section{Perec/Joyce}

From the outset, Joyce occupied a pre-eminent place in Perec's literary pantheon. During the year (1954-5) he spent attending a 'classe préparatoire' (or élite university crammer) at the Lycée Henry IV in central Paris, Perec read Ulysses, later recommending Jean Paris's Joyce par lui-même to his friend Bernard Quilliet as a helpful introduction to the book. ${ }^{17}$ A number of Perec's earliest writing plans involved deliberate Joycean imitation. The Madman, a lost piece of work written in 1956, when Perec was 20, opened with a pastiche of Joyce. Two years later, he planned to write the fourth part of his first novel, Gaspard, in a form of interior monologue inspired by Ulysses. ${ }^{18}$ There were passages of Joycean pastiche in the next (long lost and recently rediscovered) version of the same novel, entitled Le Condottiere. ${ }^{19}$ A more substantial rewriting project, conceived in 1962, shows the scale of Perec's ambition:

Perec imagined rewriting Ulysses and improving on it. Perec's Joycean project, entitled Le Portulan ('The Mariner's Chart') [...] would follow two friends on an all-night bar-crawl around Paris as they talked of beer and of bladders, of the nature of reality, and of language. ${ }^{20}$

\footnotetext{
${ }^{14}$ Guy Debord, 'Situationist Manifesto' [1960], in 100 Artists' Manifestos: From the Futurists to the Stuckists, ed. Alex Danchev (London: Penguin Classics, 2011), 347-50, 349.

${ }^{15}$ Bellos, 280-1 and 363. '[A]ny text', wrote Kristeva, 'is constructed as a mosaic of quotations': 'any text is the absorption and transformation of another'. - Julia Kristeva, 'Word, Dialogue, and Novel' [1966], in Desire in Language: A Semiotic Approach to Literature and Art, ed. Leon S. Roudiez, trans. Thomas Gora, Alice Jardine, and Leon S. Roudiez (New York: Columbia University Press, 1980), 64-91, 66.

${ }^{16}$ Georges Perec and Kaye Mortley, 'The Doing of Fiction' [extracts from a tape-recorded conversation in English transcribed by Jane Byrne], in Review of Contemporary Fiction, 'Georges Perec Issue', Vol. 29, Issue 1, 94-101, 96. The OuLiPo's first meeting was held in Paris in November 1960. On the group's beginnings, see Bellos, 3489. At its gatherings Perec became close to Raymond Queneau (to whose memory Life A User's Manual is dedicated), Harry Mathews, Jacques Roubaud, François le Lyonnais, Italo Calvino, among others.

${ }^{17}$ Bellos, 144.

${ }^{18}$ Bellos, 194. For more on Perec's comments about Joyce at this time, including his plans to reread Ulysses, see Bellos, 159 and 190.

${ }^{19}$ Bellos, 218 and 229-30.

${ }^{20}$ Bellos, 280.
} 
Although plans for such narrowly targeted rewritings receded from Perec's ambitions, the works he did write testify - in both their minor details and their overarching structures - to his abiding admiration for Joyce's oeuvre.

Isolated parallels, considered together, gather resonance. For example, as Joyce published the first three stories of Dubliners under the pseudonym of Stephen Daedalus before giving the same name to the autobiographical protagonist of Stephen Hero and A Portrait (notwithstanding the elision of the surname's initial A in the latter), so Perec wrote an early review under the pseudonym of 'Serge Valène' before bestowing the same name upon the protagonist through whom Life is focalized. ${ }^{21}$ In Species of Spaces (1974), to take another example, Perec reminisces as follows:

Long ago, like everyone else I presume [...] I used to write my address as follows:

Georges Perec
18, Rue de l'Assomption
Staircase A
Third floor
Right-hand door
Paris 16e
Seine
France
Europe
The World
The Universe

Although no Joycean intertext is made explicit, the superfluously detailed address, nesting the individual within larger, and finally infinite, spaces, strongly recalls Stephen Dedalus's childhood wonder in A Portrait, at his own microcosmic place within the universal macrocosm. ${ }^{23}$ This preoccupation - concerning the relationship between part and whole, fragment and totality - was to remain a dominant strand in Perec's subsequent literary responses to Joyce.

Indeed, the allusion to A Portrait in Species of Spaces adumbrates Perec's interest in Ulysses's segmentation - or divisibility into episodes - as an antecedent to Life A User's Manual's modular structure. Further, it is tempting to see a link between the Gilbert schema, reproduced by Jean Paris in Joyce par lui-même, and the 'scaffolding' Perec painstakingly assembled as the 'skeleton' for his Life. ${ }^{24}$ This fascination with meticulous structures extended to the

\footnotetext{
21 'The Sisters', 'Eveline', and 'After the Race' were published under this name in The Irish Homestead, on (respectively) 13 August, 10 September, and 7 December 1904. The review was of Pays sans Justice ('Land without Justice'), 'the first volume of the memoirs of the dissident Yugoslav Communist leader Milovan Djilas, Tito's former associate and subsequent bête noire'; it appeared in Lettres nouvelles, Issue 3, 18 March 1959, 22. See Bellos, 210.

${ }^{22}$ Georges Perec, Species of Spaces and Other Pieces, ed. and trans. John Sturrock (London: Penguin Classics, 1997), 84. Perec commented on this passage from Species of Spaces in 1981, in an explicit analogy to literary space, and the author's work to insert himself within 'the space of writing' - Perec, 'Entretien avec Ewa Pawlikowska' [1981], Litératures, no. 7, Printemps 1983, 69-77, 72.

23 'Stephen Dedalus/Class of Elements/Clongowes Wood College/Sallins/County Kildare/Ireland/The World/The Universe' - James Joyce, A Portrait of the Artist as a Young Man, ed. Jeri Johnson (Oxford: Oxford University Press, 2000), 12.

${ }^{24}$ Paris, 160-1 (Paris omits the final column of the Gilbert schemata, entitled 'Correspondences'). Perec described his preparatory labours as follows: 'To start with, I had 420 elements which were distributed in groups of 10:
} 
relationship between each of an author's works and the expanding textual space of his entire oeuvre. Perec's ambition, as he explained in 1979, was to ensure that each of his texts would include allusions to his own prior writings. The aim was

to link my various books to each other, to create a network in which each book incorporates one or several elements from an earlier book (or even a later book: a book which is still but a project or a book currently under construction) ${ }^{25}$

Each of his works, he stated, could be envisaged as a piece in the jigsaw puzzle of his own unfinished oeuvre, that oeuvre itself assuming its place within an ever evolving, ever unfinished literary system:

one must begin with the image of the puzzle, or perhaps the image of an unfinished book, of an unfinished 'oeuvre' within a forever unfinished literature. I think of each of my books as belonging to a whole; a whole which itself belongs to a much vaster whole consisting of the body of books which sparked and stoked my desire to write. ${ }^{26}$

Within the expanding system of Perec's own works, Life A User's Manual 'imposed itself not simply as a "next book" amongst others, but as the book which would swallow up and surpass them all'. ${ }^{27}$ The similarity between Perec's conception of his corpus and Jean Paris' description of Joyce's oeuvre is striking. Commenting on Joyce's persistent focus on Dublin and the strong sense of interconnectedness it fosters between his works, Paris notes that

such an evolution is without equal in literature: it has entirely to do with the conquest of an ever more extended universe [...] no image can convey it better than that of circles on water, each work issuing from the preceding one, dissolving into another, larger one, mobilizing a series of words, themes, and symbols in continual expansion, as though it tended, at its limit, to melt into the cosmos. ${ }^{28}$

The link Paris emphasizes here between the local and the universal resonates with Perec's own fascination with the relationship between, on the one hand, the specificity of particular places and the infinity of the cosmos, and, on the other hand, the written fragment and the expanding literary totality in which it is inscribed.

The rest of this essay will focus on Life A User's Manual, examining the ways in which quotations from Ulysses are deployed within the novel, and showing how Perec's complex,

colours, numbers of characters per room, events like American before Christopher Columbus, Asia in ancient times, or the Middle Ages in England, details about the furniture, literary quotations, etc. All this provided me with a sort of skeleton; each chapter was to integrate some of these elements. This was my personal scaffolding which I spent two years building.' - Perec in interview with Jean-Jacques Brochier, Le Magazine littéraire, 141 (October 1978), 35 - quoted and trans. by Jacques Mailhos, in 'The Art of Memory: Joyce and Perec', in Transcultural Joyce, ed. Karen Lawrence (Cambridge: Cambridge University Press, 1998), 151-169, 158.

${ }^{25}$ Georges Perec, Interview with Sidaner, L'Arc 76, 1979, 3-10, 5.

${ }^{26}$ Ibid, 3.

${ }^{27}$ Bellos, 578.

${ }^{28}$ Jean Paris, Joyce par lui-même (Paris: Éditions du Seuil, 1957), 76. Jean Paris emphasizes the systematicity of Joyce's work at several points; of Ulysses - which in his account sounds markedly like one of the constraint-ruled productions of the Oulipo - he states for instance that: Ulysses is described in a way which would make it eligible for classification among the texts of the Oulipo: "neither disorder nor chance play any part in it. There is not an image, not a chord, not a nuance of this composition that does not answer to exact rules, carefully calculated relations, and very erudite intentions.' (124) 
rule-governed intra- and intertextual system relates to Joyce's own extreme intertextual practices.

\section{Joyce in Perec's Life}

Life A User's Manual is about the many people who live, or have lived, in a Parisian apartment block, no. 11 rue Simon-Crubellier - an ordinary building on an ordinary street. It is about a painter, Valène, whose project is to paint the building as it would look if its façade were removed. ${ }^{29}$ And it is about Bartlebooth, a man who decides to spend his entire adult life in pursuit of an artistic project which is as vast and consuming as it is seemingly futile. For ten years, Bartlebooth - whose name amalgamates 'Bartleby', Hermann Melville's scrivener, and 'Barnabooth', Valery Larbaud's millionaire itinerant dilettante - plans to study the art of painting. ${ }^{30}$ For the next twenty years, he will travel the world, painting 500 different marinas at a rate of one a fortnight. Each of these paintings will be sent back to 11, rue Simon-Crubellier, where a contracted associate, named Gaspard Winckler, will apply Bartlebooth's watercolours to wooden backings and cut them into jigsaw puzzles. On his return, Bartlebooth will reassemble the puzzles, at a rate, again, of one a fortnight. Each completed puzzle will be dispatched to the place of its original conception. The watercolour will be detached from its wooden backing, and a chemical solution applied to its surface to dissolve the paint without damaging the paper. Finally, the remaining blank sheet will be destroyed on the spot. Thus nothing whatsoever will remain of Bartlebooth's fifty-year project. The enterprise, by literalizing the idea of the artwork as a puzzle, dramatizes Perec's fascination with the imbrication of part and whole, the individual work and the oeuvre of a lifetime. Bartlebooth's vast operation provides the most developed plotline in the novel, but it is far from being the only one. Indeed, Bartlebooth's is but one of the 178 stories listed in the book's Alphabetical Checklist of Some of the Stories Narrated in this Manual, involving but a clutch of the 1400 characters the Index inventories. ${ }^{31}$

In addition to the Index (running to 40 pages) and Alphabetical Checklist, the Appendix includes a Chronology and a Postscript, ${ }^{32}$ in which it is revealed, at the very last minute and in parentheses, that:

(This book contains quotations, some of them slightly adapted, from works by: René Belleto, Hans Bellmer, Jorge Luis Borges, Michel Butor, Italo Calvino, Agatha Christie, Gustave Flaubert, Sigmund Freud, Alfred Jarry, James Joyce, Franz Kafka, Michel Leiris, Malcolm Lowry, Thomas Mann, Gabriel Garcia Marquez, Harry Mathews, Herman Melville, Vladimir Nabokov, Georges Perec, Roger Price, Marcel Proust, Raymond Queneau, François Rabelais, Jacques Roubaud, Raymond Roussel, Stendhal, Lawrence Sterne, Theodore Sturgeon, Jules Verne, Unica Zürn.) $)^{33}$

\footnotetext{
${ }^{29}$ The Art of Living, Saul Steinberg's drawing of 1949, was one of Perec's stated sources of inspiration for Life see Species of Spaces, 40-45.

${ }^{30}$ Herman Melville, Bartleby, The Scrivener [1853]; Valery Larbaud, A.O. Barnabooth [1922].

${ }^{31}$ Both the Index and the Checklist are (it seems safe to assume, deliberately) incomplete.

${ }^{32}$ A map of 11 rue Simon-Crubellier and the special arrangement of its interiors is provided at the end of the text, just before the Appendix.

${ }^{33}$ Life, 579; Vie, 636.
} 
By this mischievous final twist, Perec reveals a novel which had seemed a highly original, dazzlingly realistic universe unto itself, to have in fact been a veritable mosaic, tissue, or puzzle of quotations (all of which are images the text metafictionally deploys). ${ }^{34}$

By the time he embarked on the composition of Life A User's Manual in the autumn of 1976, Perec had been assembling a compendium of textual materials and elaborating a scaffolding of formal 'constraints' by which to orchestrate them, for several years ${ }^{35}$. The document Perec referred to as his Cahier des charges - a legal phrase denoting a list of obligations - is a strict prospective list of the book's contents and structures (again, it is difficult, viewing so monumental a table, not to think of Joyce's half-retrospective schema for Ulysses). ${ }^{36}$ Figure 1 shows his compendium of lists ('Tableau général des listes'), and Figure 2 reproduces a list of the constraints governing the makeup of Chapter 23, with Joyce's name appearing in fourth place. ${ }^{37}$

\footnotetext{
${ }^{34}$ Other metafictional objects (rings, paintings, sculptures) abound - as Bernard Magné and La Motte among many others, have shown: see especially Bernard Magné, 'Le puzzle, mode d'emploi: petite propédeutique à une lecture métatextuelle de La Vie, mode d'emploi de Georges Perec', Texte: Revue de critique et de théorie littéraire, n 1, 1982, 7-14; Magné, 'Lavis mode d'emploi', in Cahiers George Perec 1: Colloque de Cerisy (Juillet 1984) (Paris: P.O.L Éditions, 1985), 232-246; and Warren F. Motte, Jr, 'The Poetics of Experiment: A Study of the Work of George Perec (Lexington, Kentucky: French Forum, 1984), especially Chapter VII, 'Metaliterature'.

${ }^{35}$ Bellos, 578 and 598. For detailed accounts of this very complex system of constraints, see David Bellos, 'Literary Quotations in La Vie Mode d'Emploi', French Studies, Volume XLI, No. 2 (April 1987), 181-194; the Preface to Cahier des charges de 'La Vie mode d'emploi', ed. Hans Hartje, Bernard Magné, and Jacques Neefs (Paris, CNRS Éditions, 1993); and Bernard Magné, 'Cinquième figure pour La Vie mode d'Emploi, in Cahier Georges Perec 1: 173-7; Also, by Perec himself see 'Quatre Figures pour La Vie mode d'emploi', L'Arc, no. 76, 1979, 50-53; Perec, 'Emprunts à Flaubert'; Perec, Species of Spaces, 81-9.

${ }^{36}$ A full-colour facsimile edition of Perec's Cahier des charges was published in 1993 - see note 37. | As mentioned above (see note 25), Jean Paris reproduces only one of Joyce's two grids. Gifford and Seidman give the following account of the schemas: 'The first schema was sent to Carlo Linati in September 1920; the second was loaned to Valery Larbaud late in 1921 and circulated (somewhat secretly) by Sylvia Beach during the 1920s. The second schema was first published in part in Stuart Gilbert's James Joyce's 'Ulysses' (New York, 1930; revised, 1952) and finally published in full, edited by H. K. Croessman, in James Joyce Miscellany, 2d ser., ed. Marvin Magalaner (Carbondale, IL, 1959).' See Don Gifford with Robert J. Seidman, "Ulysses" Annotated: Notes for James Joyce's "Ulysses" (London: University of California Press, 1998), p. 12n2. Both schemas are reproduced in James Joyce, Ulysses, ed. Jeri Johnson (Oxford: Oxford University Press, 1993), 734-35 and 73639 respectively.

${ }^{37}$ Cahier des Charges (no page numbers).
} 


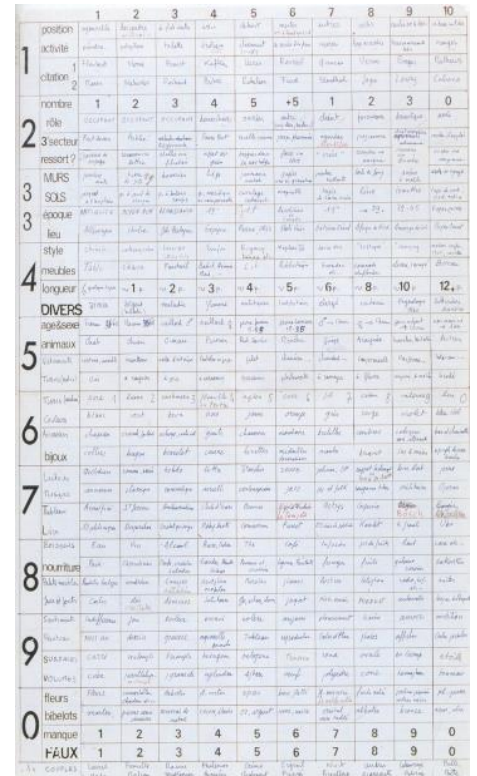

Fig. 1 .

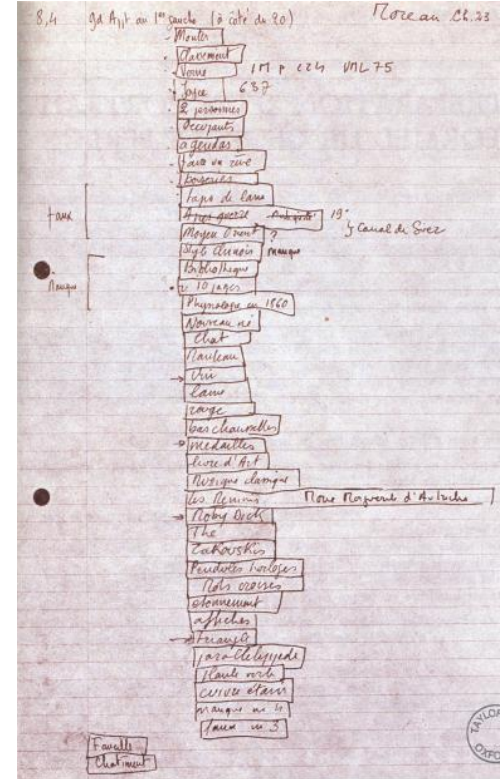

Fig. 2.

Two further notebooks - one entitled Citations, the other Allusions \& Details (Figures 4 and 4) - testify to the programmatic intertextual drive which presided over Perec's meticulous preparations.

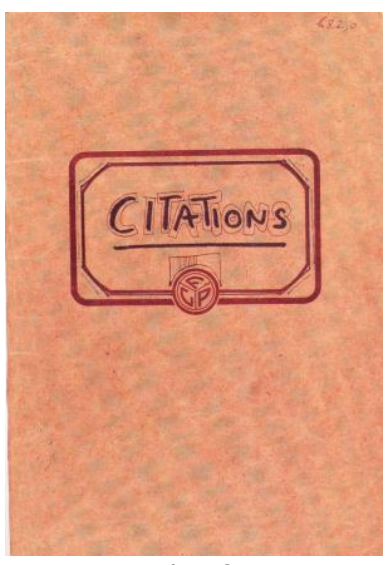

Fig. 3.

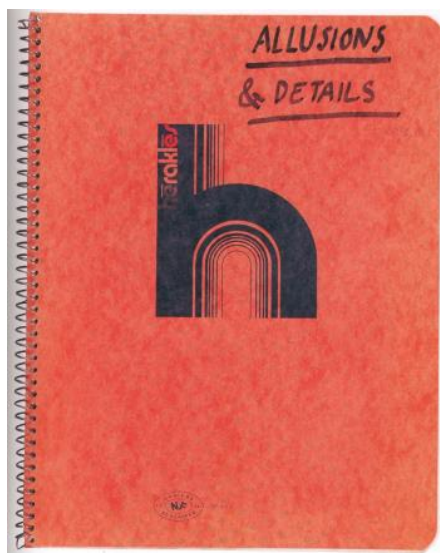

Fig. 4.

The 'Citations' notebook consists of references to quotations garnered from twenty authors. ${ }^{38}$ Here is Perec's list for Joyce (in facsimile, Figure 5, and in transcription, below):

\footnotetext{
${ }^{38}$ Joyce is one of only four English-language authors featured in the notebook (the others being Malcom Lowry, Laurence Sterne, and Harry Mathews).
} 


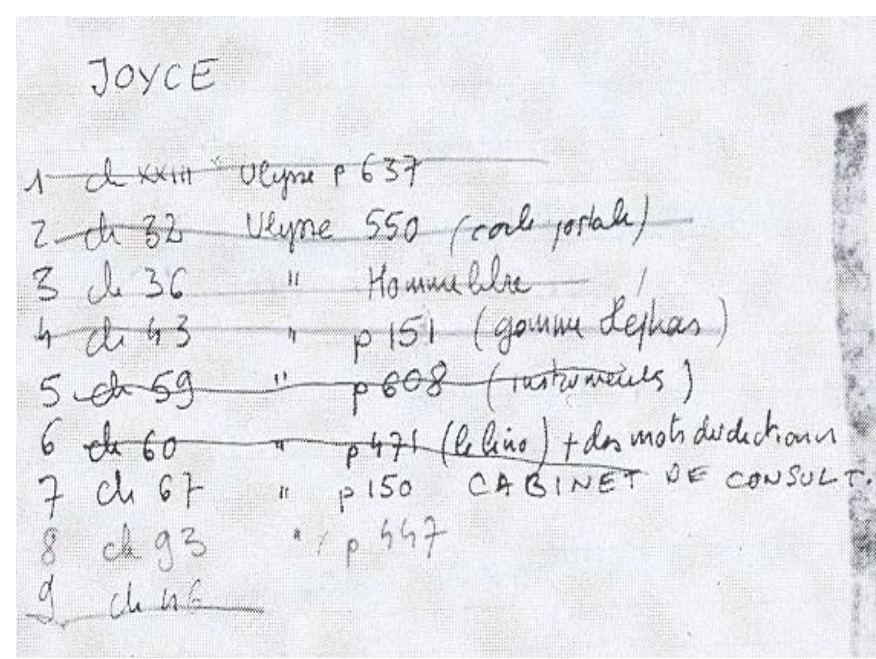

Fig. 5.

JOYCE

1 ch XXIII Ulysse p 637

2 ch 32 Ulysse 550 (carte postale)

$3 \operatorname{ch~} 36 \quad " \quad$ Homme libre

4 ch $43 \quad$ " p 151 (gomme Héphas)

5 ch $59 \quad " \quad$ p 608 (instruments)

6 ch $60 \quad " \quad$ p 471 (le lino) + des mots du dictionn

7 ch $67 \quad " \quad$ p 150 CABINET DE CONSULT.

$8 \operatorname{ch} 93 \quad " \quad$ p 447

$9 \operatorname{ch} 46^{39}$

The first column indicates each quotation's position in Perec's listing. The second indicates the number of the chapter in Life in which the corresponding quotation was to be inserted. This is followed by the title of the book from which the quotation is drawn (Ulysses, in every case, including number 9). The words in the fourth column indicate that Perec was working from the French translation produced by Auguste Morel with Stuart Gilbert and revised by Valery Larbaud and Joyce himself in 1929. The preceding pagination refers to the 1948 Gallimard edition, which, as the catalogue of Perec's library confirms, was the one he owned. ${ }^{40}$

\footnotetext{
39 'Citations' notebook, in Cahier des charges (the facsimiled pages are not numbered). The list for Joyce, featuring nine rather than ten references, is incomplete. The lack of one or two quotations from an author column is not uncommon, as the editors of the Cahier des charges observe (27); Joyce's list is alike in this regard to those for Borgès, Lowry, Flaubert, Rabelais, Sterne, Queneau, and Nabokov.

40 The half-title page attributes the translation to 'M. Auguste Morel, assisté par Stuart Gilbert, entièrement revue par Valery Larbaud et l'auteur' - Ulysse (Paris: Maison des Amis des Livres, 1929). The 'Catalogue de la bibliothèque de Perec' is available on the website of the Association George Perec, http://associationgeorgesperec.fr/IMG/pdf/Catalogue_Biblio_Perec.pdf [site accessed 8 November 2014]. The same catalogue also shows that Perec owned a 1962 Gallimard printing of Finnegans Wake, with an Introduction by Michel Butor.
} 
As the editors of the Cahier des charges note, the differences in the handwriting as well as in the inks and numeral systems (Roman or Arabic) used, show that this list (like other lists within the 'Citations' booklet) was not drawn up at one sitting, but built up gradually as Perec's novel took shape. As the text of Ulysses was altered in light of the schema Joyce drew up in 1920 and 1921 rather than being merely retrospectively tabulated in them, so Perec's prospective 'scaffolding' seems to a degree to have developed in tandem with the work it was designed to programme. ${ }^{41}$ In each case, the stages of design and composition were not as separate and sequential as might at first appear.

The following pages explore why these particular Joycean 'citations' were singled out for deployment, and analyse how are they put to use in Perec's text. (Though this essay cannot deal with all the borrowings in Perec's list - 'citations' 5, 7, and 8 are omitted from the following discussion - all are set out in detail in the Appendix). ${ }^{42}$

\section{1 ch XXIII Ulysse p 637}

The first of Perec's entries, and the only one to which the author drew attention in discussing the novel, leads to page 637 of Ulysse and, more specifically, to Bloom's dream house in 'Ithaca' - 'a thatched bungalowshaped 2 storey dwellinghouse of southerly aspect' ( $U$ 17: 1504-5). This fantasy dwellinghouse is brought to Life in Chapter 23, in which Perec's narrator tells the story of Madame Moreau, ${ }^{43}$ a farm girl turned Parisian business magnate and resident at 11 rue Simon-Crubellier. To entertain her 'distinguished guests' in style, ${ }^{44} \mathrm{Mme}$ Moreau employs a professional to redecorate her Parisian flat. Her chosen designer is one Henry Fleury - an onomastically recognizable reincarnation of Henry Flower, Leopold Bloom's own epistolary avatar. In Ulysses, Flower makes his first appearance in the 'Lotus-Eaters' episode, when Bloom is handed a letter addressed to

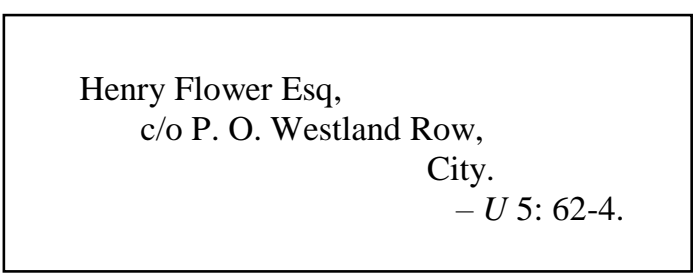

It is after this nom-de-plume that Bloom's saccharine suburban vision is dubbed 'Flowerville', or - in Ulysse - 'Fleurville'. 45

Perec's Mr Fleury takes his work for Mme Moreau extremely seriously, realizing 'what a unique opportunity he'd been given to effect his masterwork'. ${ }^{46}$ The narrator's account of his creation focuses on Moreau's sumptuous library as a 'fairly representative [example] of his

\footnotetext{
${ }^{41}$ See notes 25 and 39. Michael Groden discusses Joyce's use of the schema in the revision of the text of Ulysses in Ulysses in Progress (Princeton, NJ: Princeton University Press, 1977).

${ }^{42}$ These borrowings have received concerted attention only from Dominique Bertelli, whose unpublished PhD thesis, 'transPhormER/ECrire: Tentative d'approche du Texte signé "Perec" (Université de Toulouse-Le Mirail, 1992), devotes a chapter to an 'Exploration de l'archipel Ulysse dans La Vie mode d'emploi' (97-261).

43 The name is evidently intended to recall the Moreaux of Flaubert's Sentimental Education.

${ }^{44}$ Bloom has such 'distinguished guests' in mind ( $U$ 17: 1548).

45 'What might be the name of this erigible or erected residence? / Bloom cottage. Saint Leopold's. Flowerville.' $(U$ 17: 1579-80). Flower makes a number of subsequent appearances, notably in 'Circe' and in 'Ithaca'.

${ }^{46}$ Life, 98; Vie, 131.
} 
work' ${ }^{47}$ The fourth of its five display cases features a doll's house 'representing a typical English cottage down to the smallest detail'48. The cottage is Bloom's, excerpted from Ulysse almost verbatim (the differences from the French 'original' - that is, the French translation are marked in bold):

1 drawingroom with baywindow (2 lancets), thermometer affixed, 1 sittingroom, 4 bedrooms, 2 servants' rooms, tiled kitchen with close range and scullery, lounge hall fitted with linen wallpresses, fumed oak sectional bookcase containing the Encyclopaedia Britannica and New Century Dictionary, transverse obsolete medieval and oriental weapons, dinner gong, alabaster lamp, bowl pendant, vulcanite automatic telephone receiver with adjacent directory, handtufted Axminster carpet with cream ground and trellis border, loo table with pillar and claw legs, hearth with massive firebrasses and ormolu mantel chronometer clock, guaranteed timekeeper with cathedral chime, barometer with hygrographic chart, comfortable lounge settees and corner fitments, upholstered in ruby plush with good springing and sunk centre, three banner Japanese screen and cuspidors (club style, rich winecoloured leather, gloss renewable with a minimum of labour by use of linseed oil and vinegar) and pyramidically prismatic central chandelier lustre, bentwood perch with fingertame parrot (expurgated language) $-U$ 17: 1520-1535.

NB: Bellos's translation of this passage in clearly bears the marks of his reference to Joyce's text, reinstating (presumably accidentally) a number of words and phrases Perec had deliberately excised. For further detail, see Appendix, page 28. un salon avec baywindow (ogives à double lancette), y compris le thermomètre, un petit salon, $\mathbf{4}$ quatre chambres à coucher, $\boldsymbol{z}$ deux chambres de domestiques, $\mathbf{1}$ une cuisine carrelée avec fourneau et office, un hall avec placards à linge, et un dispositif de rayons de bibliothèques en chêne teinté contenant l'Encyclopedia Britannica et le New Century Dictionary, des panoplies d'anciennes armes médiévales et orientales, un gong pour les repas, une lampe d'albâtre, une jardinière suspendue, un appareil téléphonique en ébonite avec l'annuaire à côté, un tapis Axminster de haute laine à fond crème et bordure trellissée, une table à jouer la mouche avec pied central à griffes, une cheminée avec garniture en cuivre massif, et, sur la cheminée, une pendule de precision en ormolu, mouvement garanti avec carillon de Westminster, un baromètre-hygromètre, des canapés confortables et des coins recouverts en peluche rubis avec d'excellents resserts et un centre dans lequel on enfonce, un paravent japonais à trois panneaux et des crachoirs (style des grands clus, beau euir rouge vin qui retrouve son brilliant avec un minimum de peine par l'emploi d'huile de vin et de vinaigre), un lustre central à chandeliers avec des pendeloques en forme de prismes pyramidaux, un perchoir en bois courbé et un avec son perroquet assez apprivoisé pour se percher sur undoigt (répertoire expurgé) - Vie, 133; with changes from Ulysse, 637, marked in bold).

After mention of the parrot ${ }^{49}$, the remainder of the sentence departs from the minutiae of Joyce's text but continues to emulate its compulsive cataloguing energies. The enumerative drive which animates Joyce's 'Ithaca' likewise suffuses Perec's evocation of

hundreds of everyday objects, baubles, crockery, clothes, all reproduced almost microscopically with manic accuracy: ${ }^{50}$

The colon gives rise to yet another inventory which, with typical irony, does not, this time, reproduce a source-text with the 'manic accuracy' evinced in the preceding clauses. This species of slightly misaligned metafictional commentary is common in Life, and, furthermore, characteristic in functioning all at once as a clue and a red herring. It is a clue insofar as some form of manic fidelity is indeed at work; but it is a red herring in the sense that the accuracy involved is not of the realistic kind the description tacitly implies, for these doll's house objects have not actually been 'reproduced' from anywhere except from Bloom's cottage, which, even within the already fictional context of Ulysses, is mere fabulation - a dream doll's house in a

\footnotetext{
${ }^{47}$ Life, 98; Vie, 131.

${ }^{48}$ Life, 99; Vie, 133.

49 In this instance, Bellos's translation perhaps accidentally betrays his knowledge of Perec's Joycean source: though Perec's parrot is nowhere referred to as tame (though he is described as 'fingertame' in Ulysses and 'tame enough to perch on a finger' in Ulysse), Bellos adds a strictly superfluous 'tame' to his own version's mention of the parrot.

${ }^{50}$ Life, 99; Vie, 133.
} 
dream cottage embedded in a work of literature. The doll's house's referent, in other words, is purely intertextual. The façade of punctilious denotative realism (Fleury's, Perec's) thus gives ways, under scrutiny, to a complex textual layering of imaginary architectures. By dint of this authorial duplicity - indeed, this fictional triplicity - Perec's 'Fleurville' turns into 'Hoaxville'. That Perec associates such convoluted game-playing with Joyce's precedent is strongly suggested by the fact that when a town bearing the improbable name of 'Hoaxville' makes its appeareance in Life's $69^{\text {th }}$ chapter, it does so in close alliance with a character - 'Morrell of Hoaxville' - who bears the same name (notwithstanding a slight misspelling) as Ulysses's lead translator, Auguste Morel. ${ }^{51}$

Because the depiction of Bloom's dreamhouse evinces the same exhaustive cataloguing impulses as Perec's novel, its incorporation is seamless, absolutely unrecognizable but for readers intimately familiar with Ulysses and alert to such hints as the appearance of Mr Fleury. As well as blending perfectly into Perec's prose, the inclusion, if detected, lends metafictional colouring to the passage, seeming to tell us about the kind of writer Perec himself aspires to be. ${ }^{52}$ In fact, the quotation was first revealed as quotation by Perec himself in 1980 when, in the special issue of L'Arc devoted to him, he disclosed that 'The house of which Leopold Bloom dreams at the end of Ulysses has become the doll's house of page 135. ${ }^{53}$ Clearly, this was a 'slightly adapted quotation' Perec wanted readers to know about. As with Joyce's circulation of the Ulysses schema, such Perecquian disclosures suggest a desire to avert the risk that readers might remain oblivious to the thoroughgoing intertextuality and extreme ingenuity underpinning his project. As Joyce's grids point his readers to the precedent of Homer's epic, so Perec arouses his readers' intertextual curiosities, intimating the possibility of a complete detective mapping of his adapted borrowings.

\section{$\underline{2 \text { ch } 32 \text { Ulysse } 550 \text { (carte postale) }}$}

Perec's second entry leads to that moment in 'Eumaeus' when the unnamed sailor with whom Bloom and Stephen engage in faltering conversation in the cabman's shelter

fumbled out a picture postcard from his inside pocket which seemed to be in its way a species of repository and pushed it along the table. The printed matter on it stated: Choza de Indios. Beni, Bolivia.

All focussed their attention at the scene exhibited, a group of savage women in striped loincloths, squatted, blinking, suckling, frowning, sleeping amid swarms of infants (there must have been a score of them) outside some primitive shanties of osier. ( $U$ 16: 472-7).

\footnotetext{
51 'Morrell of Hoaxville' appears in the same sentence as a reference to 'aeolian harps' - Life, 329; Vie, 394.

${ }^{52}$ Moreover, the passage features a number of items included in Perec's 'Tableau general des listes', and if we look at the list of the 42 constraints applied in Chapter 23, we find 'tapis de laine', 'Bibliothèque', 'laine', 'rouge', 'Pendules horloges', and 'cuivre' - all of which are present in the quoted excerpt. It is possible, having noted this congruence between the material objects Perec required and the material objects Joyce's passage features, to hypothesize that in writing Life Perec deliberately chose quotations which allow for a substantial amount of overlap with the contents of his generative and prescriptive grid. This telescoping of different kinds of compositional 'constraint' exacerbates the sense of over-determination which pervades Perec's text, reinforcing the impression of a creative system in which nothing has been left to chance. Bernard Magné writes about such telescoping in relation to the many paintings described in the book: see 'Lavis mode d'emploi', in Cahiers George Perec 1: Colloque de Cerisy (Juillet 1984) (Paris: P.O.L Éditions, 1985), 232-246, 241.

${ }^{53}$ Perec, 'Quatre Figures', 52. This is also the only quotation from Joyce detected by Gabriel Josipovici in his 'Georges Perec's Homage to Joyce (and Tradition)', The Yearbook of English Studies, Vol. 15, 'Anglo-French Literary Relations' Special Number (1985), 179-200, 200.
} 
In Chapter 32 of Life A User's Manual the Bolivian postcard makes a cameo appearance as one of a long list of items resting on a low table. The sixth of these is

a postcard bearing the legend Choza de Indios, Beni, Bolivia, exhibiting a group of savage women in striped loincloths, squatted, blinking, suckling, frowning, sleeping, amid a swarm of infants, outside some primitive shanties of osier ${ }^{54}$

In neither of its fictional destinations - Dublin, 1904, Paris, 1975 - does the card give rise to comment.

Again, Perec's text produces extended, near verbatim, quotation from the French translation of Ulysses, with the alterations consisting of cuts and a tiny number of changes to verbal forms (past tenses give way to present participles), effected so as to allow the transplant - one of Life's many contending images for the citational process - to 'take'. ${ }^{55}$ To think in the metafictional terms the book invites, this is a postcard from James Joyce - a postcard which has traversed time, space, and linguistic barriers. As with Perec's inscription of Bloom's fantasy dwellinghouse in Chapter 23, the postcard from Bolivia is so seamlessly inserted into the fabric of its new fictional world as to make the detection of an intertextual link extremely unlikely. The discovery that the card is in fact a mere trompe l'oeil transforms the illusion of fictional 'depth' (that is, of a fully realized, independently imagined world) into an impression of mere citational surface.

The card itself seems an emblem of the translational fabric - in several senses - of Perec's book as a whole. In Ulysses, a visual image is rendered into English. Life, drawing on a French translation of Joyce's text, again translates the object (both spatially and linguistically) into its own fictional milieu. These various practices of translation tie in with one of the book's chessthemed constraints, which dictates the progress of the narrative through 11, rue SimonCrubellier in a pattern determined in accordance with the directional translations required by 'the knight's tour' (a sequence of chess moves by which the knight visits every square exactly once). This system of compounded, layered translations adds to the picture of an author intent on the concealment of his writing techniques - that is, on the successful hoaxing of his readers through the multiplication of different leads. But beyond this, it is also representative of Perec's sense of all writing as a realm of vectorised translation (in which later writing is determined, and indeed generated, by earlier writing) and intertextual collaboration (in which all writers are envisaged as contributing to literature in all its expanding, unfinalized totality). ${ }^{56}$

\section{$\underline{3 \operatorname{ch} 36 " \text { Homme libre }}$}

The third of the entries in Perec's table specifies no page number, but Chapter 36 of Life, the quotation's assigned destination, is, at just a page in length, much shorter than most, making

\footnotetext{
${ }^{54}$ Life, 152-3. The details of Perec's reworking of his French 'originals' are shown in the Appendix.

${ }^{55}$ Lino Margay, for instance, whose face is 'horribly disfigured' after a motorcycling accident, benefits from 'a proteolytic graft technique which allowed scar tissue to regrow without leaving any marks' - Life, 354-358. Such images of organic intertwining sit in tension with others - such as that of the puzzle - which imply the maintenance of clearly demarcated boundaries between the fragments out of which artistic assemblages are made.

${ }^{56}$ Alison James considers 'Oulipian writing as a form of translation' in 'The Maltese and the Mustard Fields: Oulipian Translation', SubStance, Issue 115, Volume 37, Number 1, 2008, 134-47, 134; Dennis Duncan offers an in-depth exploration of the thematics of translation in Oulipian writing in 'Tropes of Translation and Conceptions of the Subject in the Work of the Oulipo’, Ph.D., Birkbeck, University of London, 2011.
} 
detection of Perec's version of 'Homme libre' straightforward. The chapter principally concerns Hermann Fugger, a German industrialist who, for reasons that remain unexplained, is carrying a copy of The Freeman's Journal under his arm:

Il a sous le bras un quotidien de Dublin - The Free

Man - dont on peut lire la manchette

NEWBORN POP STAR WINS PIN BALL CONTEST
He carries under his arm a Dublin daily - The Free Man - on which the following headline can be read:

NEWBORN POP STAR WINS PIN BALL CONTEST

This interpolated headline is immediately followed by another graphic insert, representing the newspaper's advertisement for a travel agency:

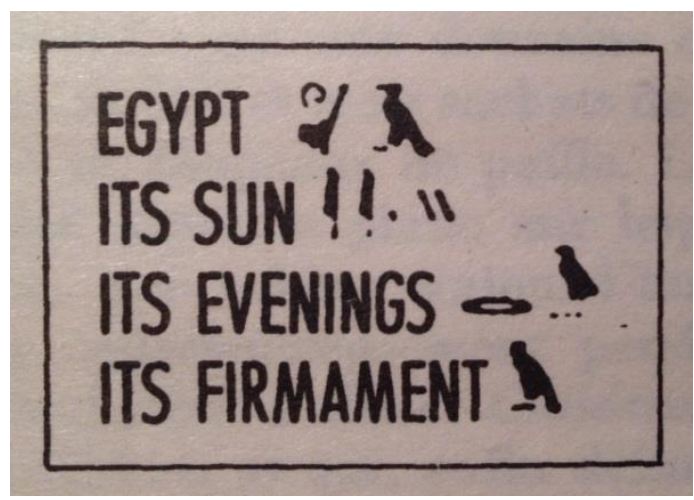

Fig. 6 (Life, 166).$^{57}$

Who is Hermann Fugger? And why does he have The Freeman's Journal - a Freeman's Journal which immediately generates an 'Aeolus'-like newspaper headline and an ad Bloom might have conceived - under his arm?

Fugger is a plausible name for a rich German industrialist, having been borne by one of the wealthiest banking families in the world. Hermann, meanwhile, recalls Melville, one of the authors who meant the most to Perec, whose Moby Dick appears in Perec's list of 'Books', ${ }^{58}$ and whose scrivener Bartleby lends half his name to Life's Bartlebooth. But the suspicious interpretative speculation Perec's 'Joyce' table invites yields more. Hermann Fugger shares his initials with Henry Flower and Henry Fleury; likes cooking, as does Leopold Bloom; and has a link - as did the historical Fuggers - to the Habsburgs, which Bloom, as it turns out, also has (more on this later). These parallels are off-set by the contrast between the masculine ('Herr', 'Mann') and punning, sexualised ('Fugger') connotations of the German name and the delicate femininity suggested by 'Bloom' and 'Flower'. The joke involving the multiplication of Bloom's avatars in the book reaches a high point in Chapter 71 when Mme Moreau and Hermann Fugger (among other guests) feast together in the dining room Fleury designed for her. ${ }^{59}$

\footnotetext{
${ }^{57}$ Vie, 210.

58 This list is separate from the list of authors whose works are used as repositories of 'Citations'.

${ }^{59}$ Life, 343; Vie, 409.
} 
Apart from engaging in complex and virtually indiscernible onomastic play, Chapter 36 continues Perec's ludic engagement with the French translation of Ulysses. Not only is Leopold Bloom (whose surname is already a translation from the Hungarian Virag in Ulysses) now translated into German, but the title of the paper carried by his avatar is given neither in accordance with its form in the English, Joycean original (The Freeman's Journal), nor in the French version Perec copied into his 'Joyce' table' ('Homme libre'), but in a 'slightly adapted' form - The Free Man. Furthermore, the announcement about the pin ball contest is immediately followed by an advertisement - also in the form of a boxed insert - for a travel agency offering travel to Egypt, which seems a likely reference to Bloom's work as an ad canvasser for The Freeman, as well as his daydreams of Middle-Eastern locations. ${ }^{60}$

The seemingly anodyne inclusion of this 'slightly adapted' newspaper title is resonant with interpretative implications. In the speculative metafictional vein Life invites, Leopold Bloom might be seen as a 'free man', roaming from book to book and chapter to chapter, assuming onomastic disguises in chameleonic fashion as he travels. Or the title of Fugger's daily might be a reference to Perec himself, a 'free man' willing to take liberties with literary texts, perpetuating them through reinscription and adaptation. This freedom paradoxically appears the more clearly when the text's programmatic scaffolding is known to the reader - when he or she knows, in other words, that the reference to Fugger's paper is dictated by a system of constraints, and is, in consequence, not free. It is in the context of such knowledge that the adapted quotation's emphasis on freedom takes on its full mischievous piquancy, shedding light on the exercise of a creative liberty which no system of constraints - as Perec demonstrates - could substantially dent.

\section{4 ch 43 " p. 151 (gomme Héphas)}

Perec's fourth entry makes parenthetical reference to a 'gomme Héphas', 'gomme Héphas' being the French translation's rendering of the 'inkeraser Kansell' which momentarily occupies Bloom's thoughts in 'Lotus-Eaters'. Moments after seeing Hely's sandwichmen saunter past ( $U$ 8: 123-6), Bloom imagines the following exchange:

Hello, Jones, where are you going? Can't stop, Robinson, I am hastening to purchase the only reliable inkeraser Kansell, sold by Hely's Ltd, 85 Dame street. $-U$ 8: 140-2.
Ohé Jones, où allez-vous? Peux pas m'arrêter, Robinson, je cours acheter la seule gomme qui efface bien l'encre, la gomme Héphas, chez Hely et Cie, 85 Dame Street. - Ulysse, 151.

'Kansell' is of course a pun on the verb 'to cancel'. Likewise 'Héphas' is a pun on the French verb 'éffacer' - to erase, to efface. In Life's Chapter 43, we read about a grey mackintosh in which is found a cardboard box bearing the following inscription:

\footnotetext{
${ }^{60}$ In 'Calypso', Bloom pictures himself on a mythologically tinged Eastern journey: 'Somewhere in the east: early morning, set off at dawn. Travel round in front of the sun [...] Wander through awned streets. Turbaned faces going by. Dark caves of carpet shops' (U 4: 84-9). Other examples from the include his thoughts about Frederick Diodati Thomson's In the Track of the Sun (U 4:99-100), the Zionist colony of 'Agendath Nethaim' (U 4: 191$2)$, the '[o]rangegroves and immense melonfields north of Jaffa' ( $U$ 4:194), and 'the dead sea' (U 4. 219-20).
} 


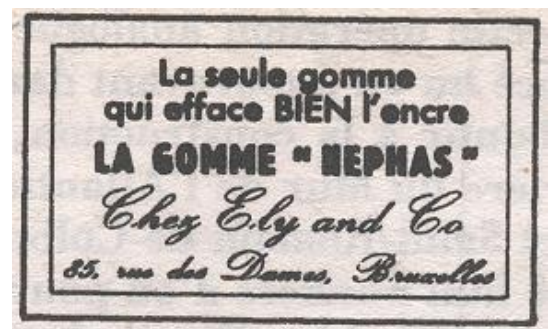

Fig. 7 (Vie, 235).

rendered in Bellos's English translation as

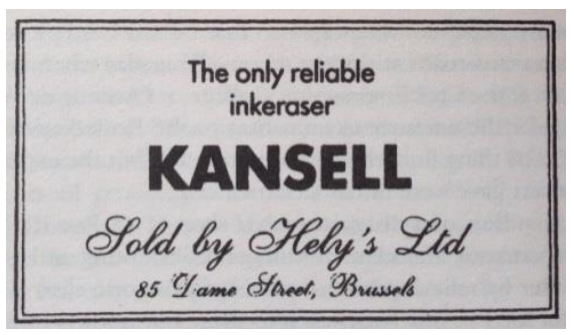

Fig. 8 (Life, 186).

This kind of graphic interpolation-cum-translation - also seen in Perec's third ('Free Man') quotation from Ulysses - is a frequent occurrence in Life. Here, as in Chapter 23, which literalizes Bloom's imagined house, a purely mental conception is actualized. Dublin's Dame Street is moved (that is, spatially translated) to Brussels (as in Chapter 36 a copy of The Freeman's Journal was spatially translated to Paris), where it becomes, in accordance with the requirements of linguistic translation, the 'rue des Dames'. Hely's loses its initial $\mathrm{H}$ in translation, the letter seemingly becoming subject to the 'Kanselling' or 'héphasing' processes it advertises (or is it that 'Héphas's superfluous H costs Hely's its initial aspirate in an act of scrupulous balancing?). Confoundingly, however, that mobile $\mathrm{H}$ reclaims its place in the company's name on the very next page, when we discover that we shouldn't have believed our eyes at all, for

Il n'existait pas de Maison Hély and Co à Bruxelles - Vie, 236.

There was no Hely's Ltd in Brussels - Life, 188.

So Hely's or Ely's does not exist in this fictional world after all. The firm, it emerges, was merely invented to serve as cover for a resistance fighter hiding from the Gestapo. This example again displays the intricacy of Perec's intertextual hoaxing: first, cultivating our confidence in the meticulously realistic veneer of his novel by seeming to include a real ad; then drawing attention to its own part in an elaborate confidence trick. As so often in Life, a trick at the level of story acts as a cover to a textual - typically, intertextual - infiltration: in this case, the more deeply concealed hoax consists in the ad's derivation from literature rather than from life).

The icon promoting Hely's 'gomme Héphas' ties into the novel's thematics of erasure. Ironically imparting high visibility on the page to an object whose purpose is to reduce visibility, it functions as an apt emblem of Perec's own conflicting impulses to both hide and reveal. In W or the Childhood Memory (1975), Perec compares his own experience of writing to that of 'a child playing hide-and-seek, who doesn't know what he fears most: to stay hidden, or to be found'. ${ }^{61}$ As Ewa Pawlikowska suggests, these contending desires underpin all of

${ }^{61}$ Bellos, 595. 
Perec's writing. They are technically and metafictionally writ large, for instance, in $L a$ Disparition, a novel-length lipogram in which the letter ' $E$ ' never features. ${ }^{62}$ Bellos discusses these conflicting wishes in the context of disagreements about the divulgation of generative constraints among members of the Oulipo. Thus Henry Matthews held that the scaffolding of an author's methods had no business entering the public domain, while Italo Calvino saw it as the Oulipo's duty to educate the reading public about the mechanisms involved in the genesis of art (as Gide had done by publishing his Journal des Faux-Monnayeurs for instance). According to Bellos, 'Perec held, simultaneously and awkwardly, the views of both Mathews and Calvino', 63

In Life, these contradictory urges to conceal and reveal are encapsulated in Bartlebooth, whose rule-governed life-project establishes an exact equation between creation and destruction: 'no trace would remain of an operation which would have been, throughout a period of fifty years, the sole motivation and unique activity of its author' ${ }^{64}$. Bartlebooth wants absolutely everything he produces - every watercolour, every completed jigsaw puzzle - to cancel/Kansell out, to come to 'nothing': 65

he wanted the whole project to come full circle without leaving a mark [...] his aim was for nothing, nothing at all, to subsist, for nothing but the void to emerge from it, for only the immaculate whiteness of a blank to remain ${ }^{66}$

Perec's hesitation as to whether to prioritize his twin temptations to hide and to reveal again suggests a parallel to Joyce, whose Gilbert and Linati schema for Ulysses have ever since their first circulation raised complex questions concerning their relation to his modern epic. Just as Joyce's work would undoubtedly have had a markedly different reception history had the Homeric tables not become public, so the facture of Perec's Life would probably have been impossible to reconstruct exhaustively (it is unlikely to have been so even to this day) without the aid of his rare disclosures and, most importantly, the posthumous publication of his Cahier des charges ${ }^{67}$ It is because he was so intent on preserving the secret of his work - or at least endowing its discovery with the difficulty of a serious challenge - that Perec built error into his productive system of constraints. Of the role of 'error' in the distribution of literary quotations in the book, Bellos writes that

the achievement of perfection, completeness, oneness, is not so much 'subverted' as prevented by design. One consequence of the randomizing effect [...] is, of course, that even if an encyclopaedic reader succeeded in recognizing all of the programmed quotations, he could not reconstruct Figure 4 [which in Bellos's article illustrates the highly recondite 'magic square' Perec used to plan Life] by mathematical induction alone. ${ }^{68}$

\footnotetext{
62 Georges Perec, La Disparition (Paris: Denoël, 1969).

${ }^{63}$ As Bellos explains, on one occasion Perec's pleasure in giving into the temptation of letting readers in on his vertiginously complex designs (at the Cercle Polivanoff, on 17 May 1978) was superseded by regret and a determination not to so again. - Bellos, 593.

${ }^{64}$ Life, 119; Vie, 154.

${ }^{65}$ Bartlebooth's plans for his project's complete pre-programmed erasure are echoed by Valène's thoughts about the future destruction of the building to the memorialization of which his painting, and Perec's book, are seemingly devoted: 'One day [...] the whole house will disappear, the street and the quartier will die.' - Life, 131; Vie, 165. ${ }^{66}$ Life, 391; Vie, 462.

${ }^{67}$ See notes 37 and 38.

${ }^{68}$ David Bellos, 'Literary Quotations', 188-9. The particular form of mathematical magic square used by Perec (a 10 X 10 magic square known to specialists as a 'Graeco-Latin bi-square') is given on page 186 of Bellos's article.
} 
Although Bellos may be right about the intractability of the puzzle with which Perec confronts the reader of Life, the very extremity of the means resorted to by the author to veil his methods from view - as revealed in glimpses in articles and interviews - acts, in its very taunting deviousness, as a tease inviting matching cunning. The orchestrated deployment of error thus becomes legible as, paradoxically, a highly personal gesture - an idiosyncratic signature ambivalently poised between algorithmic mechanism and individual expression, a 'portal of discovery' leading back to its author ( $U$ 9:229). Yet if the painstaking combination of order and chaos, system and error, hinting and erasure, that is in evidence in Perec's quotations from Joyce may thus bespeak a form of authorial imprint, it may also be seen as yet another mark of affiliation. ${ }^{69}$ For as a number of critics have highlighted in recent years, Joyce's works themselves betray a sustained fascination with error. For Tim Conley ${ }^{70}$ Joyce's numerous intentional and accidental mistakes conspire to foster a pervasive 'aesthetic of error' ${ }^{71}$ In this light, the very status bestowed upon error in Perec's system of constraints suggests yet another aspect of his alignment with Joyce.

\section{6 ch $60 "$ p 471 (le lino) + des mots du dictionn}

Chapter 60's use of Ulysses is relatively atypical, involving two quotations rather than one, with each being drawn from different episodes of Ulysses (it seems possible that Perec thought of one of these as substituting for the tenth quotation omitted from his Joyce list). The appearance in 'Circe' of the word 'linoleum' - which features under 'Walls and Floors' in Perec's compendium of lists ('Tableau général des listes') allows him to satisfy two of his constraints for the chapter ('linoleum' and 'Joyce') in one go. Accordingly, Chapter 60 begins by simply rewriting a sentence from 'Circe' (Perec's alterations to the text of Ulysse appear in bold in the bottom right-hand box):

The floor is covered with an oilcloth mosaic of jade and azure and cinnabar rhomboids. - $U$ 15: 20222061.

A kitchen. The floor is covered with a linoleum mosaic of jade and azure and cinnabar rhomboids. - Life, 285.
Le parquet est couvert d'un lino, mosaïque de rhomboïdes jade, azur et vermillon. - Ulysse, 471.

Une cuisine. Sur le sol un linoléum, mosaïque de rhomboïdes, jade, azur et vermillon. - Vie, 345.

So far so straightforward.

The second part of Perec's entry - 'mot du dictionn' - is more perplexing as the phrase does not feature in either his or Joyce's text. But dictionaries certainly play an important part in this chapter of Life. The protagonist, Cinoc, kills words for a living ("he was a "word-killer"'), expurgating them from dictionaries to make room for new ones:

\footnotetext{
${ }^{69}$ For an excellent discussion of Perec's opposing drives to hide and hint (which includes a passing mention of Joyce as a precursor), see Benoît Peeters, 'Échafaudages', in Cahiers George Perec 1, 178-192.

70 See for example Tim Conley, Joyces Mistakes: Problems of Intention, Irony, and Interpretation (Toronto: University of Toronto Press, 2003) and Errears and Erroriboose: Joyce and Error, ed. Matthew Creasy, 'European Joyce Studies' (Amsterdam: Rodopi, 2011).

${ }^{71}$ Conley, Joyces Mistakes, 15.
} 
he had disposed of hundreds and thousands of tools, techniques, customs, beliefs, sayings, dishes, games, nicknames, weights and measures; he had wiped dozens of islands, hundreds of cities and rivers, and thousands of townships off the map [...] Where had all the abunas gone, patriarchs of the Abyssinian Church [...]? What had become of Léopold-Rudolph von Schwanzenbad-Hodenthaler, whose outstanding courage at Eisenuhr allowed Zimmerwald to carry the day at Kisàszony? ${ }^{72}$

Amid the words Cinoc is said to have erased from the world's vocabulary is the name of yet another incarnation of Leopold Bloom. This time Bloom is on a visit from 'Cyclops', in which he makes a fleeting appearance as Henry Flower with Martha Clifford just discernible by his side:

The delegation, present in full force, consisted of Commendatore Bacibaci Beninobenone [...], Monsieur Pierrepaul Petitépatant, the Grandjoker Vladinmire [sic] Pokethankertscheff, the Archjoker Leopold Rudolph von SchwanzenbadHodenthaler, Countess Marha Virága Kisászony Putrápesthi (U 12: 555-61)

The 'Archjoker' Bloom (whose title's echo of the 'Archduke' Franz Ferdinand's perhaps establishes a 'Habsburg' link to Hermann Fugger) bears both his own and his father's first names ('Leopold Rudolph') and a name which, translated literally from the German, means 'Penis-in-bath-Inhabitant-of-the-valley-of-testicles'. His epistolary paramour appears in matching onomastic disguise bearing a name which, 'in addition to the obvious English puns', translates from Hungarian as 'Countess Cow Somebody's-flower Mademoiselle Putrapesthi', with 'Putraspesthi' amalgamating 'putrid pest' with 'Budapest'. ${ }^{73}$ In Life, Perec retains Bloom's onomastic disguise almost verbatim while embedding the character in surroundings as nonsensical as those from which he hails. A hint of Martha is preserved in 'Kisàszony', which, however, now appears - like 'Eisenuhr' ('iron watch') - to refer to a battlefield rather than to a person. Conversely, Zimmerwald, the Swiss village in which a large international socialist conference took place in 1915 , becomes the name of a war hero.

In a typically paradoxical instance of intertextual appropriation involving both alignment and inversion with a source-text, words which stand for linguistic creativity and 'archjokery' in Ulysses are depicted in Life as words fit only for expurgation from the dictionaries of the world. And yet the very same gesture by which we are told that Cinoc the professional 'word-killer' has eliminated the words of Ulysses is the gesture (of quotation) by which Perec, undermining the 'Kansellations' of his character, keeps them alive.

This instance evinces Perec's pleasure, expressed in an interview given after the publication of Life, in 'writing a book in which characters from other books appear'. ${ }^{74}$ The same inclination drives the incorporation governed by the eighth entry in his 'Joyce' table, in which Mrs Ylverton Barry, Mrs Bellingham, and The Honorable Talboys travel from the scene of Bloom's trial in 'Circe' to the strange and anonymous fictional afterlife afforded them by Perec in Chapter 93 (see Appendix). This partiality for the 'metempsychosing' of fictional protagonists yet again bespeaks Perec's sense of literature as an expanding totality in which words and

\footnotetext{
${ }^{72}$ Life, 287-8; Vie, 347-8.

${ }^{73}$ Both translations are given in Ulysses' Annotated: Notes for James Joyce's 'Ulysses', ed. Don Gifford, with Robert J. Seidman, redv and expanded edn (Berkeley and Los Angeles: University of California Press, 1988), 334.

${ }^{74}$ Perec, Interview with Jean-Jacques Brochier, Le Magazine littéraire, 141 (October 1978), 32-35, 33.
} 
characters migrate from text to text in a pattern of 'absorption and transformation' (to quote Kristeva's definition of intertextuality) which solders together even as it alters. ${ }^{75}$

\section{$9 \operatorname{ch} 46$}

There are no words in Perec's final entry to guide the identification of a Ulysses quotation. Perec's taste for highly idiosyncratic Joycean 'nonsense', already in evidence in his memorialization of 'Cyclops's 'Léopold-Rudolph von Schwanzenbad-Hodenthaler', leads his excerpting gaze to train its sights on the same chapter's avian ventriloquy:

Ga Ga Gara. Klook Klook Klook. Black Liz is our hen. She lays eggs for us. When she lays her egg she is so glad. Gara. Klook Klook Klook. Then comes good uncle Leo. He puts his hand under black Liz and takes her fresh egg. Ga ga ga ga Gara. Klook Klook Klook. U 12: 845-9.
Cot cot cot cot codèk. Klouc klouc klouc. C'est notre poule la Noire. Pour nous elle pond des oeufs. Elle est si gaie quand elle a pondu. Cot cot. Klouk klouk klouk. Voici le bon oncle Léo. Il glisse sa main dessous elle et lui prend son oeuf frais pondu. Cot cot cot cot codèk. Klouk klouk klouk. - Ulysse, 309.

Perec takes the words of the French translation of this passage all but verbatim, omitting a single 'cot' and two grave accents on 'codèk' (indicated in bold in the quotation below), and introducing verse-like line breaks:

Cot cot cot cot codek.

Klouc klouc klouc.

C'est notre poule la Noire.

Pour nous elle pond des oeufs.

Elle est si gaie quand elle a pondu.

Cot cot.

Klouk klouk klouk.

Voici le bon oncle Léo. Il glisse sa main dessous elle et lui prend son oeuf frais pondu.

Cot cot cot eөt codek.

Klouk klouk klouk. ${ }^{76}$

It is possible, of course, that the accents and final 'cot' were omitted by mistake. But a deliberate elision seems far more likely, given what Perec's other quotations and the post-script to Life indicate about his predilection for 'slightly adapted' versions of his source texts.

The chapter in which this bizarre passage appears has a certain Mr Jérôme as its protagonist. This Mr Jérôme earns a living for many years by translating English primers of the content of which the 'black hen' ditty is said to be fairly representative:

One of them offered him translation work from English. It concerned children's books, the kind of little books called 'primers' in English-speaking countries and in which you quite often find things like [Bellos's problematic translation of Perec's

\footnotetext{
${ }^{75}$ See note 15 .

${ }^{76}$ Vie, 255. Bellos's translation, in an emphatic (if presumably wholly unwitting) demonstration of the alterations of meaning involved in translation, eradicates all trace of Perec's Joycean quotation: 'Icky licky micky sticky! I I'm a tiny tiny thing / Ever flying in the spring / Round and round a ring-a-ring / Long ago I was a king / Now I do this kind of thing / On the wing, on the wing! / Bing!' - Life, 205.
} 
'Klouk klouk klouk' passage appears here] and they obviously had to be adapted in translation so as to fit the everyday characteristics of French life. ${ }^{77}$

Thus Perec makes a man called Jérôme the translator of a passage which, far from being acknowledged as the very slightly modified, translated quotation from Ulysses that it is, is passed off as the stuff of a children's primer. The French passage given here is showcased not as the translation that it is (whether from the French Ulysse or from a fictional English primer), but as an untranslated, and in fact wholly invented example, of the general kind of text Jérôme translates from English into French.

The name of Perec's protagonist is eminently relevant to this vignette of intercrossing translations. Jérôme, a translator not by vocation but by necessity, bears the name of the patron saint of translators. It is to saint Jerôme that Valery Larbaud - who played so crucial a role in promoting Joyce's standing in France and abroad, not only in assisting with the French translation of Ulysses, but by repeatedly explaining and lauding it in speech and writing dedicated his treatise on translation, Sous l'Invocation de saint Jérôme (1946). The saint seems to have exerted a powerful fascination on Perec throughout his career, as is suggested by his works' many allusions to Antonello da Messina's painting of Saint Jérôme, ${ }^{78}$ and the fact that Jérôme is the Christian name of the protagonist of Perec's first novel, Things.$^{79}$ The translation of the Hebrew Bible into Latin for which Saint Jerome is famed, and the rigour he advocated in the accomplishment of such tasks, evidently stands in sharp contrast to the liberties taken by Perec - under the absolving cover of self-imposed OuLiPian constraints - in dealing with his own 'originals'.

Perec's final 'Joyce' entry in the 'Citations' notebook marks the climax of the self-reflexive musings about translation which seem to accompany all of Perec's borrowings from Ulysses. In the use of a translation in a passage which is about translation, it is representative of Perec's seemingly irrepressible metafictional energies in this novel, in which everything somehow seems related to Barnabooth's project, and, by extension, to Perec's own. ${ }^{80}$ And it is representative, also, of his urge, through translation, to plant his work not only within the space of French literature, but within the literature of all countries and languages, within the abstract whole of an infinite and 'forever unfinished literature'. ${ }^{81}$

\footnotetext{
${ }^{77}$ Life, 205. See note 90 for Bellos's translation of the 'Klouk klouk klouk' passage.

${ }^{78}$ See Bernard Magné, 'Le Saint Jérôme d'Antonello de Messine, oeuvre-clé du pinacotexte perecquien', in Récits/tableaux, ed. Jean-Pierre Guillerm (Lille, France: Presses Universitaires de Lille, 1994), 229-244.

${ }^{79}$ By using the name 'Jerome' again in Chapter 46 of Life, Perec satisfies one of the four 'extra' constraints he imposed on himself on top of those programmed in the Cahier des charges, namely, to refer to one of his own prior works in every chapter of Life - see Preface to Cahier des charges, 26.

${ }^{80}$ The metafictionality of Perec's writing testifies to his commitment to Queneau's call for a 'technique consciente du roman'. Queneau's advocacy of the importance of a fully 'conscious' novelistic technique, maximizing authorial control and minimizing the role of chance, is set out in 'Technique du roman', in Bâtons, chiffres et lettres (Paris: Gallimard, 1965), 28. Queneau, to whose memory Life is dedicated, was a fervent admirer of Joyce's, and may have fuelled Perec's own Joycean enthusiasms - see Brandon Kershner, 'Joyce and Queneau as novelists: A Comparative Study' (unpublished PhD thesis, Stanford University, 1971). See also Sam Slote, “"Odd's without Ends”: Raymond Queneau and the Twisted Language of the Wake' in James Joyce: The Study of Languages, ed. Dirk Van Hulle (Brussels: Peter Lang, 2002), 23-35, and "“Après mot le déluge" 2: Literary and Theoretical Responses to Joyce in France' in The Reception of James Joyce in Europe, ed. Geert Lernout and Wim Van Mierlo, Vol. 2 (London: Thoemmes Continuum, 2004), 382- 410.

${ }^{81}$ Perec, Interview with Sidaner, L'Arc 76, 1979, 3-10, 3. For more on Perec's and the Oulipo's fascination with translation, see Alison James, 'The Maltese and the Mustard Fields: Oulipian Translation' in SubStance, \# 115, Vo. 37, no. 1, 2008, 134-147 and Dennis Duncan, 'Tropes of Translation and Conceptions of the Subject in the Work of the Oulipo' (unpublished PhD thesis, Birkbeck, University of London, 2011).
} 


\section{Beyond constraint: stylistic and formal intertextualities}

Perec's allusions to Joyce in Life go well beyond the prescriptions of his own table. While references to 'The Man in the Mackintosh' ${ }^{82}$ (the phrase appears as a book title), a blind piano tuner, ${ }^{83}$ 'Daedals', mazes, and labyrinths, ${ }^{84}$ æeolian harps,${ }^{85}$ cyclopses,${ }^{86}$ and gigantism, ${ }^{87}$ all give rise to suspicions of Joycean allusion, stylistic and formal intertextualities are even more remarkable. Encyclopaedism, for instance, is writ large in Life. Lists of all kinds - inventories, catalogues, bibliographies, dictionaries, encylopaedias - feature with bewildering frequency. ${ }^{88}$ And as in Ulysses, this urge to exhaustive representation leads to the inclusion of a large amount of pictorial and typographically distinct material. Numerous inserts - newspaper headlines, bibliographies, advertisement billboards, drawings, titles, crossword puzzles, chessboard grids, genealogical trees - punctuate the text. Certain inclusions of this kind seem particularly Joycean. The reproduction of the title page of a Haydn symphony (Fig. 9) calls to mind the score featured on the pages of 'Ithaca' ( $U$ 17: 828-9).

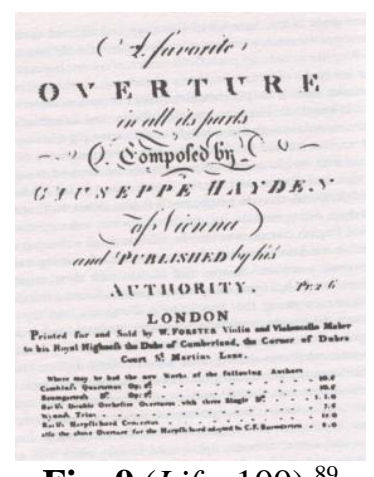

Fig. 9 (Life, 100) ${ }^{89}$

The table of her calorie-consumption which Anne Breidel inscribes in her diary for 16 June 1975 (Fig. 10), is, like Bloom's budget for 16 June 1904 in 'Ithaca', significantly mendacious.

\footnotetext{
82 'L'Homme à l'imperméable' is unfortunately translated by Bellos as 'The Waterproof Man' - Vie, 98; Life, 68. In fact, Life's 'man in the mackintosh' seems as likely to be derived from Robbe-Grillet's Les Gommes (1953) another important intertextual source for Chapter 43's 'gomme Héphas' - as from Joyce's mystery man. In Chapter 43 of Life, it will be recalled, the box on which is inscribed the advertisement for the 'Héphas' eraser is found in the pocket of a grey mackintosh. - Life, 185; Vie, 234.

${ }^{83}$ Life, 6, 371, 497. The piano tuner's second mention is shortly followed by a reference (apparently unrelated) to Wolfe Tone.

${ }^{84}$ Life, 360, 494; Vie, 428, 575 (the 'dédales' of Vie are lost in Bellos's translation).

${ }^{85}$ Life, 329; Vie, 394.

${ }^{86}$ Life, 187, 361; Vie, 236, 429.

${ }^{87}$ Life, 485; Vie, 565 - 'gigantisme' is rendered as 'elephantiasis' in Bellos's translation.

${ }^{88}$ Mme Moreau's four-page hardware catalogue makes the listings of 'Cyclops' or 'Ithaca' seem positively effusive - Life, 101.

${ }^{89}$ Life, 100; Vie, 134.
} 


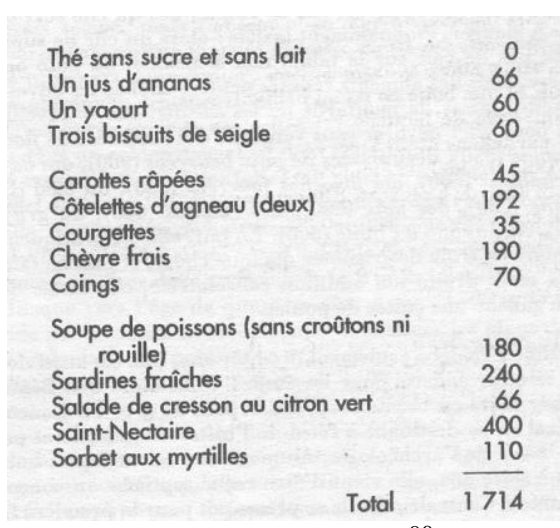

Fig. $10(\text { Vie }, 223)^{90}$

More obviously, 'JOYCE (James Augustine Aloysius), romancier irlandais, 1882-1941)' is included (along with Fleury, Fugger, Jérôme, Morel, and Léopold-Rudolph von Schwanzenbad-Hotenthaler) in the forty-page Index provided in the Life's Appendix. ${ }^{91}$ With typical mischievousness, however, the page number given in the entry refers only to the appearance of Joyce's name in Perec's Postscript (which in fact comes after the Index), and not to his many other hoaxing 'appearances' in the form of 'slightly adapted' quotations. Moreover, the Chronology which immediately follows the Index, spanning 1833 to 1975, features, without comment, the following entry:

\section{June: Bloom's Day ${ }^{92}$}

The key to this inclusion would seem to lie outside the novel. Life, though not itself set on 16 June 1904, takes place on a single day, indeed in a single instant: the instant, just before 8 p.m., in which Bartlebooth dies, and the instant in which all of Valène's thoughts about 11, rue Simon-Crubellier and the painting by which he would like to immortalize it, rush in. In Jean Paris's book about Joyce, Perec would have seen a cartoon illustration of 'Bloomsday', representing the various events of 16 June 1904, and read 'what 16 June 1904 stood for: the day Joyce met his future wife, and probably became her lover' ${ }^{93}$ Perec's date for Life is a conceptual if not calendric Bloomsday: his chosen date, 23 June 1975, commemorates the day on which his love affair with Catherine Binet began. ${ }^{94}$

\section{A piece in the puzzle}

What is to be made of this profusion of 'slightly adapted' Joycean quotations and allusions in Perec's Life ${ }^{95}$ In 1985, Gabriel Josipovici claimed that

\footnotetext{
${ }^{90}$ Life, 177.

${ }^{91}$ Life, 532, 523, 524, 531, 541, 553.

92 Life, 565; Vie, 625.

${ }^{93}$ Paris, 136 and 163.

${ }^{94}$ Bellos, 566 and 634.

${ }^{95}$ Few of these have been noted. Josipovici spots the re-appearance in Life of Bloom's dream cottage (previously pointed out by Perec in 'Quatre Figures', 52) - Josipovici, 200. Dominique Bertelli recognizes Léopold Schwanzenbad-Hodenthaler on his visit from 'Cyclops' - 'TransPhormER/ECrire', Études littéraires, vol. 23, $\mathrm{n}^{\circ}$ 1-2, 1990, p. 159-168, 159; Jacques Mailhos mentions both the Kansell eraser as well as Flowerville, without, however, providing much elucidation as to their roles in 'The Art of Memory: Joyce and Perec' in Transcultural Joyce, ed. Karen Lawrence (Cambridge: Cambridge University Press, 1998), 151-169, 161-2, and 164-5.
} 
La Vie mode d'emploi is a homage to tradition, the storehouse of possibilities. In particular it is a homage to Joyce, the man who above all others made it possible. ${ }^{96}$

Tempting though it may be to place Joyce at the pinnacle of Perec's pantheon in this way, Josipovici's assertion in fact drastically overstates the case. ${ }^{97}$ As Perec himself commented, Life evinces a markedly different attitude to quotation from that which is reflected in the predominantly Flaubertian tenor of Things and in his contemporary wish to act as a Borgesian Pierre Ménard to Melville's Bartleby. In Life, he explained in 1980, the act of quotation is far more plural, being expressive not of a binary relationship to another author, but functioning instead as 'the sign of a surveying, the tracing of a network' ${ }^{98}$

Although Perec's quotations from Joyce in Life generate particular kinds of intertextual comedy - relating, for instance, to the acts of translation that they both enact and represent they are not of a significantly different kind from the quotations from other authors featured in Perec's book of 'Citations'. Joyce was undoubtedly of great importance to Perec - as his writing and statements about writing amply testify - but in Life a deliberate structural levelling of all the novel's components prevails: the tabular lists in his Cahier des charges, the use of an organizational pattern drawn from chess, and the complex mathematical formulae that govern the narrative, preclude the possibility of one author being elevated above another. Evenly weighted, these assembled quotations form a gigantic intertextual puzzle strikingly fitting Kristeva's definition of the intertextual text as a 'mosaic of quotations'. 99

To quote in this way, for Perec, is to delineate a personal microcosm within the literary macrocosm. As he explained in 1979:

My ambition as a writer is [...] to survey, or at least to chart, the field of writing in all the domains which have enabled me to write. This implies an engagement with genres, codes, and with the models from which my writing proceeds: a certain number of authors (from Joyce to Hergé, from Kafka to Price, from Scève to Pierre Dac, from Si Shônagon to Gotlib) define and circumscribe the space from which I write. $^{100}$

\footnotetext{
96 Josipovici, 200.

${ }^{97}$ As Bellos also points out: ' $V M E$ is structurally just as much a homage to Sterne, to Nabokov, to Queneau, to Rabelais, etc.' - 'Literary Quotations', 187.

98 'Emprunts à Flaubert', 40. Perec's early interest in repeating particular texts (rather than producing a Life-like mosaic) is clear from his ambition, expressed in 1965, shortly after the publication of Things, to rewrite Melville's 'Bartleby': 'of course, my aim isn't to rewrite Don Quixote, like Borges's Pierre Ménard [sic], but I would for instance like to rewrite my favourite Melville story, 'Bartleby the Scrivener'. It's a text that I wanted to write: but since it's impossible to write a text that exists, I wanted to rewrite it - not to pastiche it, but to make a new Bartleby - well, the same one actually, but a bit more... as if it were me who'd done it.' - 'Georges Perec Owns Up: An Interview', 28.

99 See note 14. The same point is made by Ewa Pawlikowska, whose foregrounding of Kristeva's definition of intertextuality as 'transposition' suggestively captures Perec's own interest in combining spatial and linguistic translations. - Ewa Pawlikowska, 'Citation, prise d'écriture', Cahier Georges Perec 1, 213-225, 218. Metatextual references to the art of mosaic abound in Life. It will be recalled that one of Perec's quotation from 'Circe' - one of the two listed sixth in his table of Joyce quotations - adapts a lino featuring a 'mosaic of jade and azure and cinnabar rhomboids' to its own purposes. In Chapter 53, Gaspard Winckler, Bartlebooth's puzzle-maker, mourning his wife Marguerite, holds a broach he once gave her, on which are featured 'in minute mosaics, three Paris daisies, or marguerites.' - Life, 246; Vie, 301.

${ }^{100}$ L'Arc 76, 1979, 3.
} 
For Perec, in other words, intertextuality is a means of signalling his belonging within the 'space' of literature, of inscribing his own literary coordinates within a constellation of admired pre-existing writings.

Thus Perec, like Joyce, makes intertextuality a compositional principle. ${ }^{101}$ And yet his intertextuality, Joycean in its abundance and self-consciousness, is nonetheless of a different order. The image of the jigsaw puzzle which presides over Life A User's Manual emblematizes this difference. In Life's preamble - a miniature treatise on art as intertextual jigsaw puzzle which is repeated verbatim and without explanation at the beginning of Chapter $44-$ the narrator asserts that

The only thing that counts is the ability to link this piece to other pieces [...] The pieces are readable, take on a sense, only when assembled; in isolation, a puzzle piece means nothing - just an impossible question, an opaque challenge. ${ }^{102}$

This relatively unproblematic premise leads - under the cover of metafictional metaphor - to the articulation of a highly unusual conception of the relationship between author ('the puzzlemaker') and reader ('the puzzler'):

puzzling is not a solitary game: every move the puzzler makes, the puzzler-maker has made before him; every piece the puzzler picks up, and picks up again, and studies and strokes, every combination he tries, and tries a second time, every blunder and every insight, each hope and each discouragement have all been designed, calculated, and decided by the other. ${ }^{103}$

Authorial omniscience and omnipotence are presented as absolute principles: the picture tauntingly outlined here is one of supreme, invincible intentionality. This accords with the impression of complete control produced by Perec's work, in which contingency is reduced to a finely calibrated minimum.

Yet as this essay has rehearsed, Perec was invested in error, and in particular, in Klee's idea of 'error as the genius in the system' - in deviation from the rule, or 'clinamen', as an essential source of literary vitality. ${ }^{104}$ And, as well as allowing (and indeed planning) for 'error' to play a part in his books-cum-jigsaw-puzzles, Perec was acutely conscious of his works' place within the vast, forever expanding, and fundamentally unknowable puzzle of 'all literature'. '[T]he books I have written', he reflected in 1978,

are inscribed and find their meaning in the overall image that I have of literature, yet it seems to me that I shall never fully grasp that image, that it belongs for me to a region beyond writing, that it pertains to the question of 'why I write', which I can never answer except by writing, and thus deferring forever the very moment

\footnotetext{
${ }^{101}$ For an account of Joyce's intertextual practices, see Scarlett Baron, Strandentwining Cable: Joyce, Flaubert, and Intertextuality (Oxford: Oxford University Press, 2011), 253.

${ }^{102}$ Life, n.p.; Vie, 17.

${ }^{103}$ Life, n.p.; Vie, 20.

104 'One must - and this is important - destroy the system of constraints. [...] one needs a clinamen [...] According to Klee 'the genius is the error in the system' - 'Entretien avec Pawlikowska', 70.
} 
when, by my ceasing to write, that image would visibly cohere, like a jigsaw puzzle inexorably brought to its completion. ${ }^{105}$

The puzzle-maker's god-like control, then, ultimately extends only to the boundaries of his own puzzle - but in creating that puzzle-within-a-puzzle, the shape of the wider puzzle of all literature is altered, and the 'progress' of literature ensured and inflected. ${ }^{106}$

By opening up his work to worlds of quotation - by making it the site of 'serial and massive repetition' or 'citational montage' 107 - Perec replicates the dizzyingly broad incorporative energies of Joyce's own writing. But in his idiosyncratic approach - all at once personal and impersonal, individual and Oulipian, mischievious and algorithmic - Perec adapts, translates, and transposes Joyce's intertextual vision, adding his piece to the expanding puzzle of Joycean, and universal, literature.

\section{Note on translations}

Quotations from Perec's works and extra-literary pronouncements are given in translation, as are quotations from criticism written in French. Corresponding references indicate the location of the quotation in translation and in the French original. All translations for which no reference is given are my own.

\footnotetext{
105 Georges Perec, 'Notes sur ce que je cherche', Le Figaro, 8 December 1978, quoted in David Bellos, 650-1, and reproduced as 'Statement of Intent', trans. David Bellos, in 'Georges Perec Issue', Review of Contemporary Fiction (29:1) Spring 2009, 31-32 and in 'Georges Perec Number', ed. John O’Brien, Review of Contemporary Fiction (13:1), 1993.

106 As Perec stated in 1965, 'we are moving towards a kind of art that could be called "citational", and which permits a certain progress, since the point where our predecessors finished up becomes our point of departure.' 'Georges Perec Owns Up', 27-8.

${ }^{107}$ Ewa Pawlikowska, 'Citation, prise d'écriture', 218 and 220.
} 


\section{APPENDIX}

The table below shows Perec's incorporation of quotations from Ulysses, with the four relevant texts presented in the following pattern:

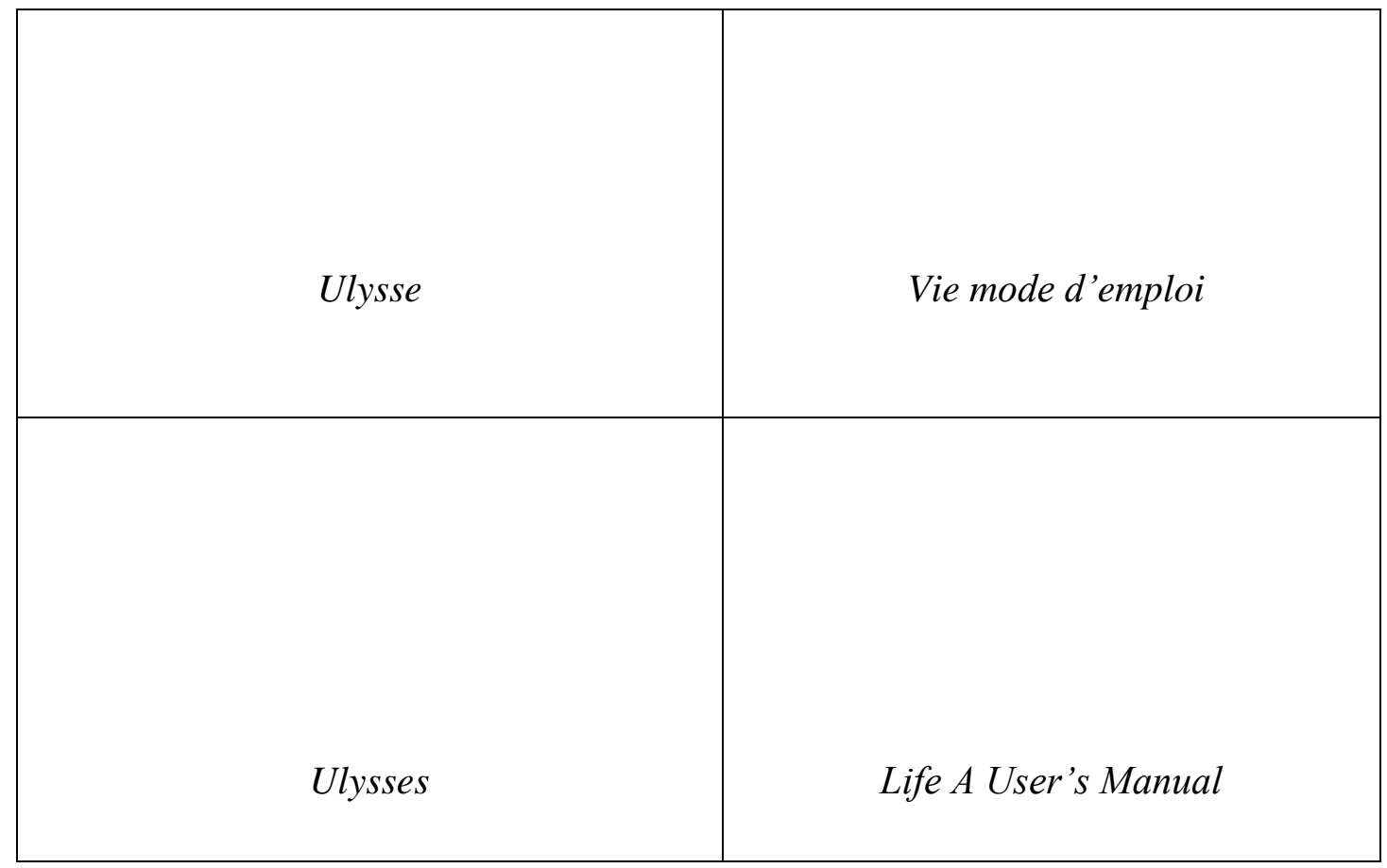

Changes made by Perec to the quotations he borrowed from Ulysse are shown in red. 


\section{1 ch XXIII Ulysse p 637}

\begin{abstract}
un salon avec baywindow (ogives à double lancette), y compris le thermomètre, un petit salon, 4 chambres à coucher, 2 chambres de domestiques, 1 cuisine carrelée avec fourneau et office, un hall avec placards à linge, et un dispositif de rayons de bibliothèques en chêne teinté contenant l'Encyclopedia Britannica et le New Century Dictionary, des panoplies d'anciennes armes mediévales et orientales, un gong pour les repas, une lampe d'albâtre, une jardinière suspendue, un appareil téléphonique en ébonite avec l'annuaire à côté, un tapis Axminster de haute laine à fond crème et bordure trellissée, une table à jouer la mouche avec pied central à griffes, une cheminée avec garniture en cuivre massif, et, sur la cheminée, une pendule de precision en ormolu, movement garanti avec carillon de Westminster, un baromètre-hygromètre, des canapés confortables et des coins recouverts en peluche rubis avec d'excellents ressorts et un centre dans lequel on enfonce, un paravent japonais à trois panneaux et des crachoirs (style des grands clubs, beau cuir rouge vin qui retrouve son brillant avec un minimum de peine par l'emploi d'huile de vin et de vinaigre), un lustre central à chandeliers avec des pendeloques en forme de prismes pyramidaux, un perchoir en bois courbe et un perroquet assez apprivoisé pour se percher sur un doigt (répertoire expurgé) - Ulysse, 637.
\end{abstract}

1 drawingroom with baywindow (2 lancets), thermometer affixed, 1 sittingroom, 4 bedrooms, 2 servants' rooms, tiled kitchen with close range and scullery, lounge hall fitted with linen wallpresses, fumed oak sectional bookcase containing the Encyclopaedia Britannica and New Century Dictionary, transverse obsolete medieval and oriental weapons, dinner gong, alabaster lamp, bowl pendant, vulcanite automatic telephone receiver with adjacent directory, handtufted Axminster carpet with cream ground and trellis border, loo table with pillar and claw legs, hearth with massive firebrasses and ormolu mantel chronometer clock, guaranteed timekeeper with cathedral chime, barometer with hygrographic chart, comfortable lounge settees and corner fitments, upholstered in ruby plush with good springing and sunk centre, three banner Japanese screen and cuspidors (club style, rich winecoloured leather, gloss renewable with a minimum of labour by use of linseed oil and vinegar) and pyramidically prismatic central chandelier lustre, bentwood perch with fingertame parrot (expurgated language) $-U$ 17: 1520-1535. un salon avec baywindow (ogives à double lancette), y compris le thermomètre, un petit salon, 4 quatre chambres à coucher, $z$ deux chambres de domestiques, 1 une cuisine carrelée avec fourneau et office, un hall avec placards à linge, et un dispositif de rayons de bibliothèques en chêne teinté contenant l'Encyclopedia Britannica et le New Century Dictionary, des panoplies d'anciennes armes medievales et orientales, un gong pour les repas, une lampe d'albâtre, une jardinière suspendue, un appareil téléphonique en ébonite avec l'annuaire à côté, un tapis Axminster de haute laine à fond crème et bordure trellissée, une table à jouer la mouche avec pied central à griffes, une cheminée avec garniture en cuivre massif, et, sur la cheminée, une pendule de precision en ormolu, mouvement garanti avec carillon de Westminster, un baromètrehygromètre, des canapés eonfortables et des coins recouverts en peluche rubis avec d'excellents ressorts et un centre dans lequel on enfonce, un paravent japonais à trois panneaux et des crachoirs (style des grands clubs, beat cuir rouge vin qui retrouve son brilliant avec un minimum de peine par l'emploi d'huile de vin et de vinaigre), un lustre central à chandeliers avec des pendeloques en forme de prismes pyramidaux, un perchoir en bois courbe et un avec son perroquet assez apprivoisé pour se percher sur un doigt (répertoire expurgé) - Vie, 133.

1 drawing room with bay windows ( 2 lancets), thermometer affixed, 1 sitting room, $\mathbf{4}$ bedrooms, 2 servants' rooms, tiled kitchen with close range and scullery, lounge hall fitted with linen wallpresses, fumed oak sectional bookcase containing the Encyclopaedia Britannica and the New Century Dictionary, transverse obsolete medieval and oriental weapons, dinner gong, alabaster lamp, bowl pendant, vulcanite automatic telephone receiver with adjacent directory, hand-tufted Axminster carpet with cream ground and trellis border, loo table with pillar-and-claw legs, hearth with massive firebrasses and ormolu mantel chronometer clock, guaranteed timekeeper with cathedral chime, barometer and hygrographic chart, comfortable lounge settees and corner fitments, upholstered in ruby plush with good springing and sunk centre, three-banner Japanese screen and pyramidically prismatic central chandelier lustre, a bentwood perch with its tame parrot Life, 99.

NB: the additions in bold in this passage indicate that Bellos worked from Joyce's text in translating this passage of $L a$ Vie, and in so doing reinstated a number of words and phrases Perec had deliberately excised. 


\section{2 ch 32 Ulysse 550 (carte postale)}

Il extirpa péniblement une carte postale illustrée de sa poche intérieure, une vraie cambuse semblait-il, et la poussa sur la table. On y lisait en caractères d'imprimerie : Choza de Indios. Beni, Bolivia, L'attention générale se concentra sur la scene representée, un groupe de femmes sauvages, accroupies dans leur pagne rayé, qui clignotant des yeux, allaitant, plissant le front, somnolant, au milieu d'un grouillement d'enfants (il devait bien y en avoir une vingtaine), sur un fond de huttes d'osier - Ulysse, 550.

He fumbled out a picture postcard from his inside pocket which seemed to be in its way a species of repository and pushed it along the table. The printed matter on it stated: Choza de Indios. Beni, Bolivia.

All focussed their attention at the scene exhibited, a group of savage women in striped loincloths, squatted, blinking, suckling, frowning, sleeping amid swarms of infants (there must have been a score of them) outside some primitive shanties of osier. $-U: 16: 472-7$. une carte postale illustrée de sa poche intérieure, une vraie cambuse semblait-il, et la poussa sur la table. On y lisait en caractères d'imprimerie : portant en légende Choza de Indios. Beni, Bolivia, L’attention générale se concentra sur la scene representée, montrant un groupe de femmes sauvages, accroupies dans leur pagne rayé, qui clignotaient des yeux, allaitaient, plissaient le front, somnolaient, au milieu d'un grouillement d'enfants (il devait bien y en avoir une vingtaine), sur un front [sic] de huttes d'osier - Vie, 194.

a postcard bearing the legend Choza de Indios, Beni, Bolivia, exhibiting a group of savage women in striped loincloths, squatted, blinking, suckling, frowning, sleeping, amid a swarm of infants, outside some primitive shanties of osier - Life, 152.

\section{3 ch 36 " Homme libre}

\begin{tabular}{|c|c|}
\hline L'Homme Libre - Ulysse, various. & $\begin{array}{l}\text { Il a sous le bras un quotidien de Dublin - The Free Man } \\
\text { - dont on peut lire la manchette } \\
\text { NEWBORN POP STAR WINS PIN } \\
\text { BALL CONTEST } \\
- \text {-Vie, } 211 .\end{array}$ \\
\hline The Freeman's Journal - U: various. & $\begin{array}{l}\text { He carries under his arm a Dublin daily - The Free } \\
\text { Man - on which the following headline can be read: } \\
\text { NEWBORN POP STAR WINS PIN BALL } \\
\text { CONTEST } \\
- \text { Life, } 166 .\end{array}$ \\
\hline
\end{tabular}




\section{4 ch 43 " p. 151 (gomme Héphas)}

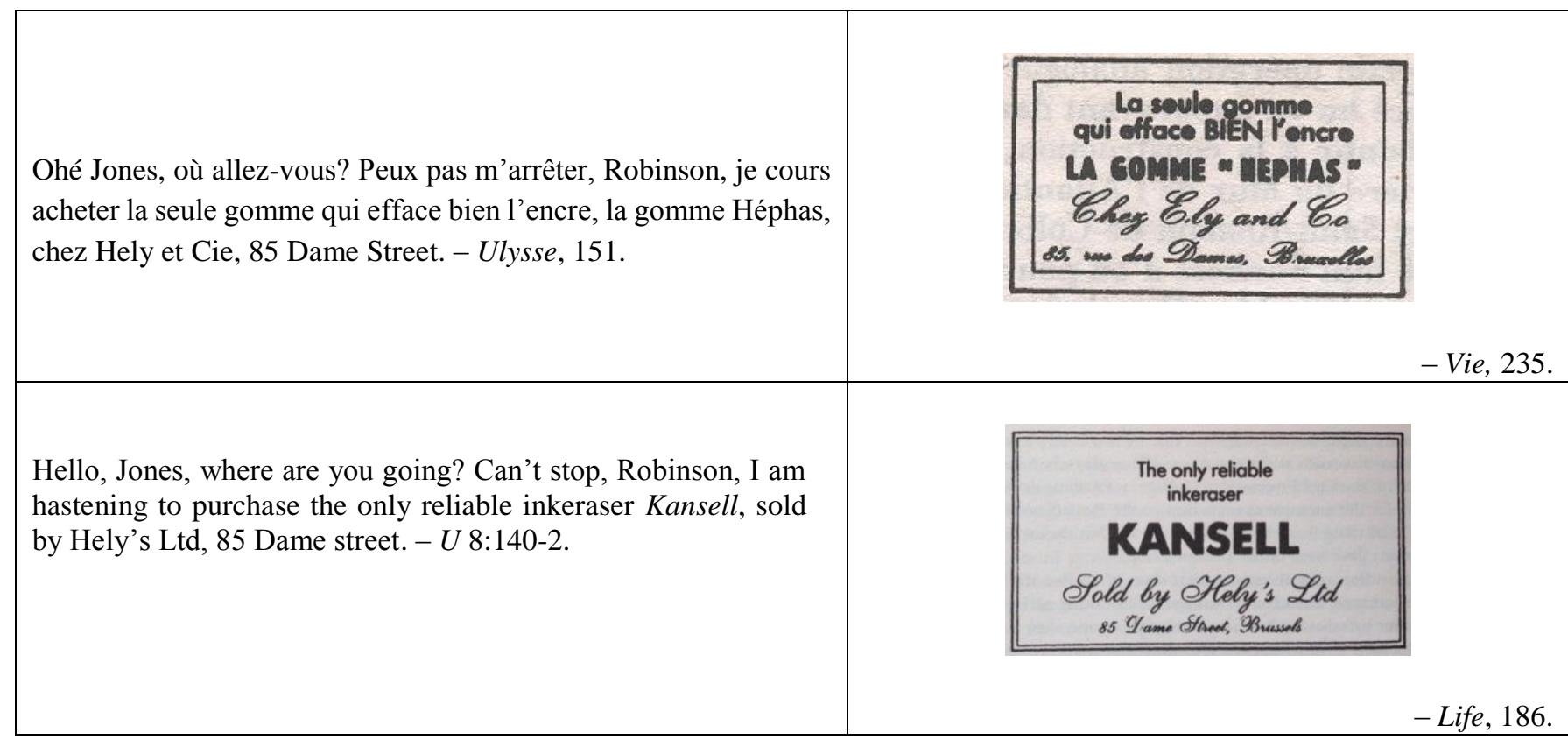

\section{Ch 59 " p 608 (instruments)}

\begin{tabular}{l|l|}
$\begin{array}{l}\text { ses kaléidoscopes astronomiques montrant les douze } \\
\text { constellations du Zodiaque d'Ariès à Piscès, des planetariums } \\
\text { miniature du genre Orrery, des chiffres en bonbons de gomme, } \\
\text { des biscuits géométriques pour faire pendant aux biscuits }\end{array}$ \\
$\begin{array}{l}\text { zoologiques, des ballons mappemondes, des poupées en costume } \\
\text { historiques. - Ulysse, 608. }\end{array}$ & $\begin{array}{l}\text { jouets divers: des kaléidoscopes astronomiques } \\
\text { montrant les douze constellations du Zodiaque } \\
\text { d'Ariès à Piscès, des planétariums miniature du genre } \\
\text { Orrery, des chiffres en bonbons de gemme, des } \\
\text { biscuits géométriques pour faire pendant aux biscuits } \\
\text { zoologiques, des ballons mappemondes, des poupées } \\
\text { en costume historiques. - Vie, 337. }\end{array}$ \\
$\begin{array}{l}\text { astronomical kaleidoscopes exhibiting the twelve constellations } \\
\text { of the zodiac from Aries to Pisces, miniature mechanical orreries, } \\
\text { arithmetical gelatine lozenges, geometrical to correspond with } \\
\text { zoological biscuits, globemap playing balls, historically } \\
\text { costumed dolls. }-U \text { 17: } 572-5 .\end{array}$ & $\begin{array}{l}\text { a tall dresser laden with books, small instruments, and } \\
\text { diverse toys: astronomical kaleidoscopes exhibiting the } \\
\text { twelve constellations of the zodiac from Aries to Pisces, } \\
\text { miniature mechanical orreries, arithmetical gelatine } \\
\text { lozenges, geometrical to correspond with zoological } \\
\text { biscuits, globe-map playing balls, historically costumed } \\
\text { dolls. - Life, 278 }\end{array}$
\end{tabular}




\section{6 ch 60 " p 471 (le lino) + des mots du diction}

\section{- (le lino)}

Le parquet est couvert d'un lino, mosaïque de rhomboïdes jade, azur et vermillon. - Ulysse, 409-10.

The floor is covered with an oilcloth mosaic of jade and azure and cinnabar rhomboids. - $U$ 15: 2022-2061.
Une cuisine. Sur le sol un linoléum, mosaïque de rhomboïdes, jade, azur et vermillon. - Vie, 345 .

A kitchen. The floor is covered with a linoleum mosaic of jade and azure and cinnabar rhomboids. Life, 285.

\section{- des mots du diction}

\begin{tabular}{|c|c|}
\hline $\begin{array}{l}\text { La délégation, au grand complet, comprenait le Commandeur } \\
\text { Bacibaci Benibenone [...]Monsieur Pierre-Paul Petit épatant, le } \\
\text { Grandturc Vlalekroumir Tiremolardoff, l'Architruc Léopold- } \\
\text { Rudolph von Schwanzenbad-Hodenthaler, la Comtesses Marha } \\
\text { Virága Kisászony Putráspethi, Hiram. Y. Bomboost - Ulysse, } \\
\text { 301. }\end{array}$ & $\begin{array}{l}\text { Qu'étaient devenus Léopold-Rudolph von } \\
\text { Schwanzenbad-Hodenthaler dont l'action d'éclat à } \\
\text { Eisenühr avait permis à Zimmerwald de remporter la } \\
\text { victoire de Kisàszony? - Vie, } 348 \text {. }\end{array}$ \\
\hline $\begin{array}{l}\text { The delegation, present in full force, consisted of } \\
\text { Commendatore Bacibaci Beninobenone [...], Monsieur } \\
\text { Pierrepaul Petitépatant, the Grandjoker Vladinmire } \\
\text { Pokethankertscheff, the Archjoker Leopold Rudolph von } \\
\text { Schwanzenbad-Hodenthaler, Countess Marha Viraga } \\
\text { Kisaszony Putrápesthi, Hiram Y. Bomboost - U 12: 555-61. }\end{array}$ & $\begin{array}{l}\text { What had become of Léopold-Rudolph von } \\
\text { Schwanzenbad-Hodentaler, whose outstanding } \\
\text { courage at Eisenühr allowed Zimmerwald to carry the } \\
\text { day at Kisàszony? - Life, } 288 \text {. }\end{array}$ \\
\hline
\end{tabular}

\section{7 ch $67 "$ p 150 CABINET DE CONSULT.}

\begin{tabular}{|l|l|}
\hline $\begin{array}{l}\text { La place rêvée. CABINET DE CONSULT. TA BINETTE DE } \\
\text { CON! Quelque client à qui il en cuit. - Ulysse, 150. }\end{array}$ & $\begin{array}{l}\text { Sur l'ancien divan de sa salle d'attente dont la toile de } \\
\text { lin, jadis verte, crevée de partout, achève de pourrir, } \\
\text { est posée une plaque de faux marbre, jadis } \\
\text { rectangulaire, aujourd'hui brisée, sur laquelle on peut } \\
\text { lire: CABINET DE CONSULT. -Vie, 390. }\end{array}$ \\
\hline $\begin{array}{l}\text { Just the place too. POST NO BILLS. POST IIO PILLS. Some } \\
\text { chap with a dose burning him. }-U \text { 8: 88-122. }\end{array}$ & $\begin{array}{l}\text { On the old waiting-room sofa whose formerly green } \\
\text { canvas upholstery is now split and rotting away, an } \\
\text { imitation-marble plaque has been put: originally } \\
\text { rectangular, now broken, it reads: CONSULTING R } \\
\text { [CABINET DE CONSULT.] - Life, 326. }\end{array}$
\end{tabular}




\section{$\underline{8 \text { ch } 93 " \text { p } 447 \text { (in fact also 448) }}$}

$\mathrm{M}^{\mathrm{me}}$ YLVERTON BARRY (Robe décolletée opale, gants ivoire douze boutons, pelisse brique ouatinée et garnie de zibeline, peigne de brilliants et pouf d'aigrettes dans les cheveux.) [...]

$\mathrm{M}^{\mathrm{me}}$ BELLINGHAM (Toque et manteau de lapin-loutre, col relevé jusqu'au menton, descend de son brougham; regard scrutateur à travers un face-à-main d'écaille qu'elle prend au fond de son vaste manteau d'oppossum.) [...]

L'HONORABLE M Me MERVYN TALBOYS (En costume d'amazone, chapeau rigide, bottes à éperons, gilet vermillon, gants mousquetaires suède avec baguettes brodées, longue traîne sur le bras et fouet de chassse avec lequel elle ne cesse de frapper l'empeigne de ses bottes) - Ulysse, 447-8.

\section{MRS YELVERTON BARRY}

(in lowcorsaged opal balldress and elbowlength ivory gloves, wearing a sabletrimmed brickquilted dolman, a comb of brilliants and panache of osprey in her hair) [...]

\section{MRS BELLINGHAM}

(in cap and seal coney mantle, wrapped up to the nose, steps out of her brougham and scans through tortoiseshell quizzingglasses which she takes from inside her huge opossum muff) [...]

\section{THE HONOURABLE MRS MERVYN TALBOYS}

(in amazon costume, hard hat, jackboots cockspurred, vermilion waistcoat, fawn musketeer gauntlets with braided drums, long train held up and hunting crop with which she strikes her welt constantly) - U 15: 984-1021. trois femmes dans un tribunal, à la barre des témoins; la premiere porte une robe décolletée opale, gants ivoire douze boutons, pelisse brique ouatinée et garnie de zibeline, peigne de brillants et touffe pouf d'aigrettes dans les cheveux; la seconde: toque et manteau de lapin-loutre, col relevé jusqu'au menton, descend de son brougham regard scrutateur à travers un face-à-main d'écaille qu'elle prend au fond se son vaste manteau d'oppossum; la troisième: en costume d'amazone, chapeau rigide, tricorne, bottes à éperons, gilet vermillon, gants mousquetaires suède avec baguettes brodées, longue traîne sur le bras et fouet de chasse avec lequel elle ne cesse de frapper l'empeigne de ses bottes; - Vie, 542.

three women in a courtroom, at the witness box; one wears a low-corsaged opal dress, and elbow-length ivory gloves, a sable-trimmed brick-quilted dolman, a comb of brilliants and a panache of osprey in her hair; the second: a cap and coat of seal coney, wrapped up to the nose, scanning the scene through tortoiseshell quizzing glasses; the third in amazon costume, hard hat, jackboots cockspur-red, waistcoat, musketeer gauntlets with braided drums, long train held up, and hunting crop; - Life, 463-4. 


\section{$9 \operatorname{ch} 46$}

Cot cot cot cot codèk. Klouc klouc klouc. C'est notre poule la Noire. Pour nous elle pond des oeufs. Elle est si gaie quand elle a pondu. Cot cot. Klouk klouk klouk. Voice le bon oncle Léo. Il glisse sa main dessous elle et lui prend son oeuf frais pondu. Cot cot cot cot codèk. Klouk klouk klouk. - Ulysse, 309.
Cot cot cot cot codèk.

Klouc klouc klouc.

C'est notre poule la Noire.

Pour nous elle pond des oeufs.

Elle est si gaie quand elle a pondu.

Cot cot.

Klouk klouk klouk.

Voici le bon oncle Léo. Il glisse sa main dessous elle et lui prend son oeuf frais pondu.

Cot cot cot eot codek.

Klouk klouk klouk. - Vie, 255.

Icky licky micky sticky!

I'm a tiny tiny thing

Ever flying in the spring

Round and round a ring-a-ring

Long ago I was a king

Now I do this kind of thing

On the wing, on the wing!

Bing! - Life, 205. 